This PDF is a selection from a published volume from the National Bureau of Economic Research

Volume Title: International Differences in the Business Practices and Productivity of Firms

Volume Author/Editor: Richard B. Freeman and Kathryn L. Shaw, editors

Volume Publisher: University of Chicago Press

Volume ISBN: 0-226-26194-8

Volume URL: http://www.nber.org/books/free07-1

Conference Date: January 2006

Publication Date: September 2009

Chapter Title: Work-Life Balance, Management Practices and Productivity

Chapter Author: Nick Bloom, Tobias Kretschmer, John Van Reenan

Chapter URL: http://www.nber.org/chapters/c0441

Chapter pages in book: (p. 15 - 54) 


\title{
Work-Life Balance, Management Practices, and Productivity
}

\author{
Nick Bloom, Tobias Kretschmer, and John Van Reenen
}

\subsection{Introduction}

Does good management and higher productivity come at the expense of work-life balance (WLB), or is good work-life balance an important component of the management of successful firms? Some more pessimistic critics of globalization have argued that competition stimulates Anglo-Saxon management practices that may raise productivity but only at the expense of well-being at work. For example, Jacques Chirac, the French president, has stressed that:

[Europe's] model is the social market economy, [the] alliance of liberty and solidarity, with the public authority safeguarding the public interest. [. . .] France will therefore never let Europe become a mere free-trade area. We want a political and social Europe rooted in solidarity. ${ }^{1}$

By contrast, a more optimistic view is often justified by citing the tangible and intangible business benefits of good WLB, sometimes espoused by the more optimistic Human Resource Management literature. For example, Tony Blair, the UK Prime minister, stated:

Nick Bloom is an assistant professor of economics at Stanford University and a faculty research fellow of the National Bureau of Economic Research. Tobias Kretschmer is a professor of management and director of the Institute for Communication Economics at the University of Munich. John Van Reenen is professor of Economics and director of the Centre for Economic Performance at the London School of Economics and a Faculty Research Fellow of the National Bureau of Economic Research.

Acknowledgments: We would like to thank the Anglo-German Foundation for their generous financial support.

1. Euractiv, "Blair, Chirac in drive to win citizens' support," October 27, 2005, (http://www .euractiv.com/Article?tcmuri=tcm:29-146484-16\&type=News). 
The UK has shown it is possible to have flexible labour markets combined with [. . . ] family friendly policies to help work/life balance [. . .]. The result has been higher growth, higher employment and low unemployment. ${ }^{2}$

Given the slower productivity growth of Europe relative to the United States since the mid-1990s $\mathrm{s}^{3}$ this question features prominently in the implementation of "catching-up strategies." If productivity and WLB are in direct conflict, employees may be asked to make sacrifices of the quality of their work-life balance. On the other hand, if favorable work-life balance is not in the way of high productivity growth or is even productivity-enhancing, the European social model may have a brighter future.

Recent policy debates have focused on issues surrounding or directly addressing issues of WLB. For example, the European Working Time Directive has been under intense scrutiny recently, with several governments in Continental Europe challenging workers' right to opt-out of the maximum ceiling of forty-eight hours a week. At the same time, the European Services Directive (designed to liberalize the movement of service workers between countries) has been interpreted as intensifying foreign competition, which may exert a heavy toll on the work-life balance of workers.

On both sides of the argument, there seem to be underlying assumptions regarding the interaction between productivity and WLB. The question of WLB-enhancing practices, their implementation, and effectiveness has been taken up in the management literature, which generally finds that:

1. WLB measures have a positive effect on firm or workplace performance. ${ }^{4}$

2. WLB measures are more effective in situations demanding high employee flexibility and responsiveness. ${ }^{5}$

3. Firms with a more skilled workforce are more likely to implement WLB-enhancing practices. ${ }^{6}$

This leaves us with a dilemma: policymakers are concerned that firms are failing to introduce sufficient measures to ensure a sensible work-life balance for their employees because the costs of doing this are too high in competitive global markets. On the other hand, the academic literature

2. Toby Helm and David Rennie, "Blair attack on 'out-of-date' Chirac," Daily Telegraph, March 3, 2005, (http://www.telegraph.co.uk/news/main.jhtml?xml=/news/2005/03/25/weu25 .xml\&sSheet $=/$ news/2005/03/25/ixnewstop.html).

3. See, for example, O'Mahony and Van Ark (2003).

4. Delaney and Huselid (1996); Huselid, Jackson, and Schuler (1997); Konrad and Mangel (2000); Perry-Smith and Blum (2000); Guthrie (2001); Budd and Mumford (forthcoming); Gray (2002).

5. For example, in high-technology industries (Arthur 2003) or in highly differentiated firms (Lee and Miller 1999; Guthrie, Spell, and Nyamori 2002; Youndt et al. 1996).

6. Gray and Tudball (2003); Osterman (1995). The percentage of female employees has a weakly positive effect on the implementation of WLB practices - see Harel, Tzafrir, and Baruch (2003); Gray and Tudball (2003); Miliken, Martins, and Morgan (1998); Martins, Eddleston, and Veiga (2002); Perry-Smith and Blum (2000); Guthrie and Roth (1999). 
seems to believe all firms should be adopting better WLB schemes given their apparently positive impact on firm performance, particularly in more competitive markets.

Our study sheds light on these contrasting views using a new large data set on over 700 firms in Europe and the United States that contains rich firm performance, management, and WLB variables. We are able to show that many of the prior results in the literature disappear when controls for management practice are included. We have already found in previous work (Bloom and Van Reenen 2007) that well managed firms tend to be more productive and more energy efficient; in this chapter we show that better managed firms also have better WLB practices. This can be seen in figure 1.1 where we simply plot our WLB outcome measure against an overall index of firm management quality (we explain the exact definitions in more detail following). Consequently, the association between firm productivity and WLB practices found elsewhere in the literature may simply be due to omitted variable bias - these regressions do not control for management quality. We show in this chapter that once we condition on management practices in the production function there is no independent role for WLB on productivity. Failure to control for the omitted variable of management leads to the spurious associations of better WLB with productivity.

The structure of the chapter is as follows: in section 1.2 we discuss our general models of management practices and firm performance. In section 1.3 we provide a detailed discussion of our data sets and the procedures

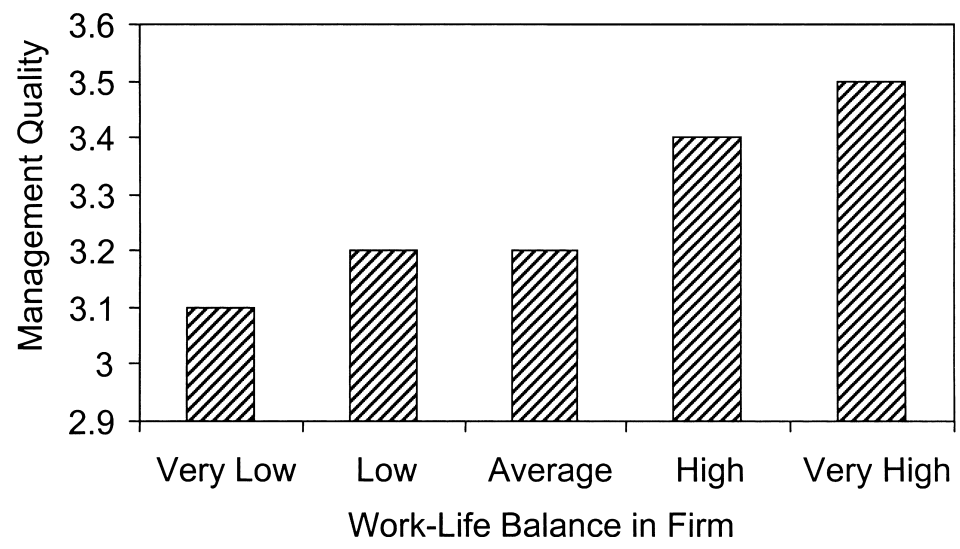

Fig. 1.1 The correlation between work-life balance outcomes and managementpractices

Notes: "Work-Life Balance in Firm" is the response to the question: "Relative to other companies in your industry how much does your company emphasize work-life balance?", where scores are as follows: "Much less" (1); "Slightly less" (2); "The same" (3); "Slightly more" (4); and "Much more" (5). "Management quality" is the average score for the eighteen individual management practice questions with scores ranging from 1 (worst-practice) to 5 (best practice). Results from 530 firm observations. 
used to collect this. In section 1.4 we discuss our results and in section 1.5 we provide some concluding comments. A detailed set of empirical appendices then follows.

\subsection{Modeling Approach}

Consider a simple approach of characterizing work-life balance, productivity, and management:

$$
\begin{aligned}
& w=f(X, M, D) \\
& y=g(X, M, D)
\end{aligned}
$$

where $\mathrm{w}=$ Work-life Balance outcomes and $\mathrm{y}=$ (total factor) productivity outcomes. The variable $X$ is an index of "good" WLB practices (such as childcare flexibility and subsidies) and $M$ is an index of "good" management practices (such as better shop-floor operations or stronger incentives). We will model these as being composite measures of several underlying practices so $M=m\left(M_{1}, M_{2}, M_{3}, \ldots\right)$ and $X=x\left(X_{1}, X_{2}, X_{3}, \ldots\right)$. Finally, $D$ is other control variables such as firm size, firm age, industry effects and country dummies, and so forth.

We would expect that better management practices should be associated with improved productivity so $\partial y / \partial M \geq 0$ (see Bloom and Van Reenen [2007] for extensive evidence). We would also expect that better WLB practices should be associated with improved reported WLB outcomes so $\partial w / \partial X \geq 0$ : this is the first thing that we examine empirically in the chapter.

What is much less clear are the cross partials in equations (1) and (2). Pessimists argue that improved WLB is costly in terms of productivity and will therefore be heavily resisted by employers, which is one reason for tough labor regulation. ${ }^{7}$ In the context of equation (1) this implies $\partial y / \partial X \leq 0$. Similarly, pessimists argue that "Anglo-Saxon" management practices come at the expense of WLB so $\partial w / \partial M \leq 0$.

By contrast, optimists from some parts of the Human Resource Management field often argue for a win-win view that improving WLB practices will increase productivity as it improves employee well-being, leading to improved recruitment and retention (e.g., of women) and better morale and motivation. In this case, $\partial y / \partial X \geq 0$. They generally also argue that better management tends to be complementary with better WLB practices, and at a minimum, there is no obvious reason why they should be strong substitutes. Thus, $\partial w / \partial M \geq 0$.

These cross partials are with respect to endogenous variables chosen by firms, so it is not obvious how to interpret these relationships. Nevertheless,

7. Even if WLB practices improved productivity they may still be resisted by employers if the costs of implementing these policies were less than their productivity benefits. 
the examination of the correlations with new data should be informative. More directly however, we also consider the more fundamental drivers of these practices. Consider a set of factors $Z\left(=Z_{1}, Z_{2}, Z_{3}, \ldots\right)$ that may exogenously affect the practices. We model management practices and WLB practices as functions of the exogenous variables as:

$$
X=h(Z, D) \text { and } M=j(Z, D) .
$$

We are particularly interested in product market competition as one of the elements of $Z$. Under the pessimist view, tougher product competition caused by globalization, liberalization, and new technologies may increase productivity through improved management practices $\partial M / \partial Z \geq 0$, but this will be at the expense of worse WLB practices and outcomes (i.e., $\partial X / \partial Z \leq$ $0)$. We examine these predictions directly in the empirical work. The optimists also view competition as a force promoting better management practices, but by contrast with the pessimists they argue that this should increase the use of good WLB practices. This is because, in their view, firms are making mistakes by not introducing better WLB practices and competition should make such profit-sacrificing strategies more costly.

To summarize, these two models yield a set of predictions laid out in table 1.1 that we subsequently test empirically. Of course, there can be "hybrid" positions between these positions. In short, we find that the evidence is inconsistent with the negative view: management practices are positively associated with WLB outcomes and there is no evidence that competition reduces WLB for workers. Nevertheless, the positive view does not receive unambiguous support: although better management and better WLB do sometimes go together, the positive correlation between WLB and productivity found elsewhere in the literature is not robust. Once we control for management we find no association of WLB with productivity. We find the evidence supports a hybrid view between the optimistic and pessimistic extremes.

\subsection{Data}

To investigate these issues we first have to construct robust measures of WLB, management practices, and competition. We discuss the collection of management and WLB data first (which was undertaken using a new firm survey tool) and then the collection of productivity and competition data (which was taken from more standard firm and industry data sources).

The data is detailed in table 1B.1 in Appendix B. Figures 1.2 and 1.3 plot some of the key cross-country averages. Looking at figure 1.2 there is a surprisingly large cross-country variation in hours worked, with French managers working about 68 percent of the annual hours worked by U.S. managers due to a combination of fewer hours per week, longer holidays, and more sick leave. United Kingdom and German managers work about 


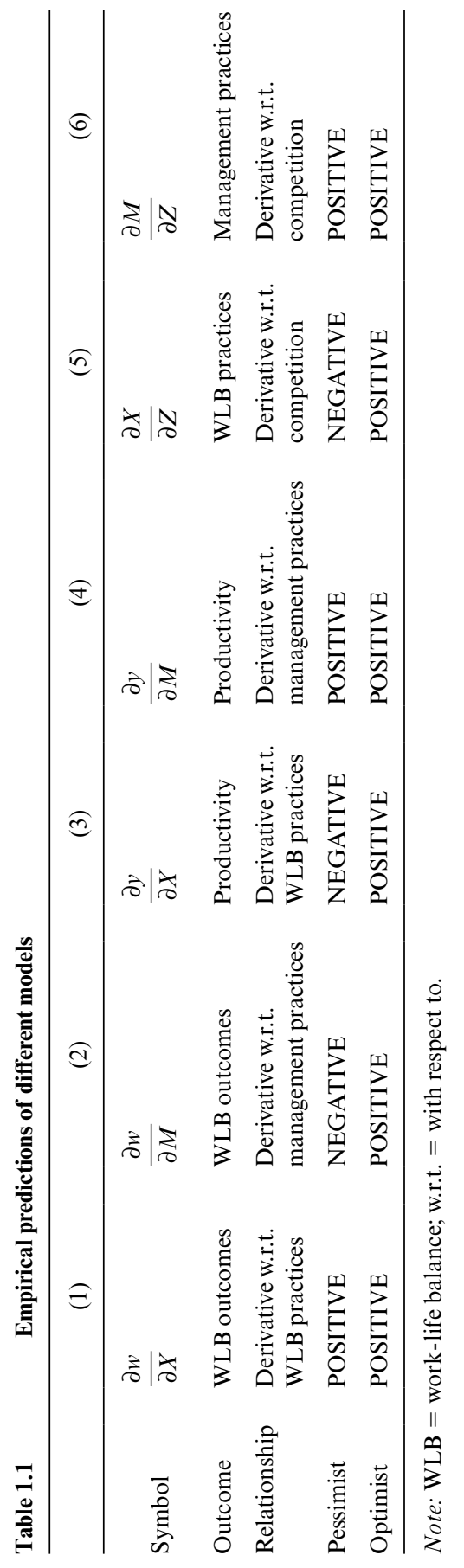




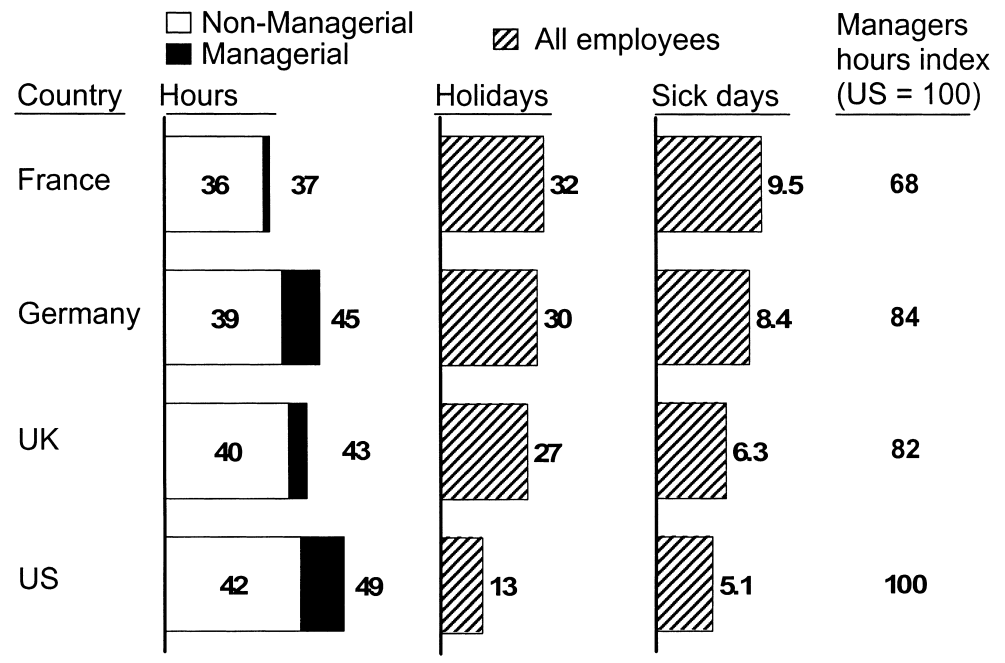

Fig. 1.2 Managerial hours vary widely by country

Notes: Country averages, per year except hours, which are per week. Average managerial hours. Assumes managers take "All employee" levels of holidays and sick leave, plus take ten days public holidays per year.

Source: Survey of 732 manufacturing firms.

82 percent and 84 percent of the U.S. managers' hours; ${ }^{8}$ about equidistant between France and the United States.

In figure 1.3 we plot the share of women in the workforce at the managerial and nonmanagerial level. Looking first at nonmanagerial female involvement, we see this is higher in the United States, with around one third of nonmanagerial female workers in the United States, compared to about one quarter in Europe. While this difference is large, the gap at the managerial level is even greater. Only 12 percent of French managers are female compared to 31 percent in the United States. Hence, not only do U.S. firms have more female employees absolutely but they also appear to have relatively more female managers. Thus, at a first glance the French policy of regulating working hours does not seem to have been effective at ensuring female participation in the workforce, and particularly in the managerial workforce, which is often seen as an indirect indicator of work-life balance.

\subsubsection{Scoring WLB and Management Practices}

Measuring WLB and management practices requires codifying these concepts into something widely applicable across different firms. This is a hard

8. The surprisingly high hours are for German managers rather than workers-who work less than their UK counterparts. 


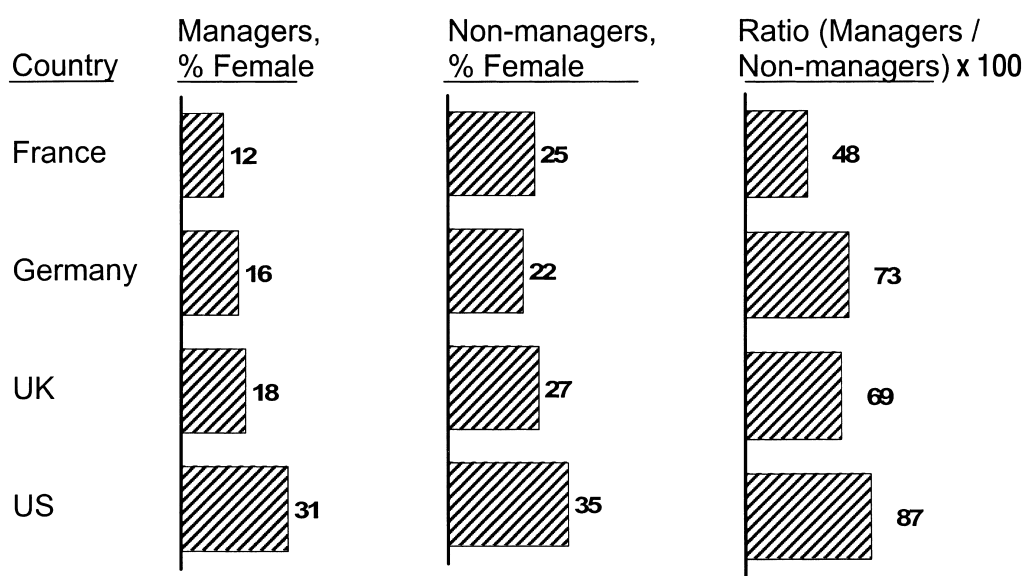

Fig. 1.3 Manager gender distribution by country Notes: Country averages.

Source: Survey of 732 manufacturing firms.

task, as WLB and good management are tough to define. To do this we combined questions that have been used previously in the: (a) Workplace Employment Survey (WERS); (b) a management practice evaluation tool developed by a leading international management consultancy firm; and (c) the prior economics and management academic literature.

\section{Work-Life Balance}

In appendix A, table 1A.2, we detail the Human Resources Interview guide, which was used to collect a range of detailed WLB practices and characteristics from firms. We collected three types of key data:

- The first was the WLB perceptions data of individuals' on their own firms WLB versus other firms in the industry. This was used as our WLB outcome measure, defined as the response to the question: "Relative to other companies in your industry how much does your company emphasize work-life balance?", scored as: Much less (1); Slightly less (2); The same (3); Slightly more (4); Much more (5).

- The second was the WLB policies/practices data on key variables including childcare flexibility, home-working entitlements, part-time to fulltime job flexibility, job-sharing schemes, and childcare subsidy schemes. This was used to construct our WLB practice measure defined as the average $z$-score ${ }^{9}$ from the five questions: "If an employee needed to take

9. For comparability to the management $z$-score this WLB $z$-score (and the management $z$-score) were both renormalized to zero mean with standard deviation one. Hence, the coefficients on both the management and WLB practice $z$-scores in the tables of results both respond to one standard deviation change in both measures. 
a day off at short notice due to childcare problems or their child was sick how do they generally do this?"; and the entitlements to "Working at home in normal working hours," "Switching from full-time to parttime work," "Job sharing schemes," and "Financial subsidy to help pay for childcare." These are all scored as yes/no.

- The third was workforce characteristic data on key variables including average employee age, hours, holidays, and proportion female, plus a full set of conditioning variables on skills (the proportion of college educated), training, and unionization. We used this data as a control for heterogeneity across firms.

\section{Management Practices}

In appendix A we detail the practices and the questions in the same order as they appeared in the survey, describe the scoring system, and provide three anonymous responses per question. These practices can be grouped into four areas: operations ( 3 practices), monitoring (5 practices), targets (5 practices), and incentives (5 practices). The operations management section focuses on the introduction of lean manufacturing techniques, the documentation of processes improvements, and the rationale behind introductions of improvements. The monitoring section focuses on the tracking of the performance of individuals, reviewing performance (e.g., through regular appraisals and job plans), and consequence management (e.g., making sure that plans are kept and appropriate sanctions and rewards are in place). The targets section examines the type of targets (whether goals are simply financial or operational or more holistic), the realism of the targets (stretching, unrealistic, or nonbinding), the transparency of targets (simple or complex), and the range and interconnection of targets (e.g., whether they are given consistently throughout the organization). Finally, incentives (or people management) include promotion criteria, pay and bonuses, and fixing or firing bad performers, where best practice is deemed to be an approach that gives strong rewards for those with both ability and effort. A subset of the practices has similarities with those used in studies on HRM practices, such as Ichniowski, Shaw, and Prenushi (1997), Black and Lynch (2001), and Bartel, Ichniowski, and Shaw (2004).

Since the scaling may vary across practices in the econometric estimation, we convert the scores (from the 1 to 5 scale) to $z$-scores by normalizing by practice to mean zero and standard deviation one. In our main econometric specifications, we take the unweighted average across all $z$-scores as our primary measure of overall managerial practice ${ }^{10}$ but we also experiment with other weightings schemes based on factor analytic approaches.

There is legitimate scope for disagreement over whether all of these mea-

10. This management $z$-score was then renormalized to zero mean and standard deviation one. 
sures really constitute "good practice." Therefore, an important way to examine the external validity of the measures is to examine whether they are correlated with data on firm performance constructed from company accounts and the stock market.

\subsubsection{Collecting Accurate Responses}

With this evaluation tool we can, in principle, provide some quantification of firms' WLB and management practices. However, an important issue is the extent to which we can obtain unbiased responses to questions from firms. In particular, will respondents provide accurate responses? As is well known in the surveying literature (see, for example, Bertrand and Mullainathan [2001]), a respondent's answer to survey questions is typically biased by the scoring grid and anchored toward those answers that they expect the interviewer thinks is "correct." In addition, interviewers may themselves have preconceptions about the performance of the firms they are interviewing and bias their scores based on their ex-ante perceptions. More generally, a range of background characteristics, potentially correlated with good and bad managers, may generate some kinds of systematic bias in the survey data.

To try to address these issues we took a range of steps to obtain accurate data:

- First, the survey was conducted by telephone without telling the managers they were being scored. ${ }^{11}$ This enabled scoring to be based on the interviewer's evaluation of the actual firm practices, rather than the firm's aspirations, the manager's perceptions, or the interviewer's impressions. ${ }^{12}$ To run this blind scoring we used open questions (i.e., "Can you tell me how you promote your employees?"), rather than closed questions (i.e., "Do you promote your employees on tenure [yes/no]?"). These questions target actual practices and examples, with the discussion continuing until the interviewer could make an accurate assessment of the firm's typical practices. Typically, three to four questions were needed to score each practice.

- Second, the interviewers did not know anything about the firm's financial information or performance in advance of the interview. This was achieved by selecting medium-sized manufacturing firms and by providing only firm names and contact details to the interviewers (but no financial details). These smaller firms would typically not be known by

11. This survey tool has been passed by Stanford's Human Subjects Committee. The deception involved was deemed acceptable because it is: (a) necessary to get unbiased responses; (b) minimized to the management practice questions and is temporary (we send managers debriefing packs afterwards); and (c) presents no risk as the data is confidential.

12. If an interviewer could not score a question it was left blank, with the firm average taken over the remaining questions. The average number of unscored questions per firm was 1.3 percent, with no firm included in the sample if more than three questions were unscored. 
name and are rarely reported in the business media. The interviewers were specially trained graduate students from top European and U.S. business schools, with a median age of twenty-eight and five years prior business experience in the manufacturing sector. ${ }^{13}$ All interviews were conducted in the manager's native language.

- Third, each interviewer ran over fifty interviews on average, allowing us to remove interviewer fixed effects from all empirical specifications. This helped us to address concerns over inconsistent interpretation of categorical responses (see Manski 2004), standardizing the scoring system.

- Fourth, the survey instrument was targeted at plant managers, who are typically senior enough to have an overview of management practices but not so senior as to be detached from day-to-day operations of the enterprise.

- Fifth, a detailed set of information was also collected on the interview process itself (number and type of prior contacts before obtaining the interviews, duration, local time-of-day, date, and day-of-the week), on the manager (gender, seniority, nationality, company and job tenure, internal and external employment experience, and location), and on the interviewer (we can include individual interviewer fixed effects, timeof-day, and a subjective reliability score assigned by the interviewer). Some of these survey controls are significantly informative about the management score (see table 1B.2), ${ }^{14}$ and when we use these as controls for interview noise in our econometric evaluations the coefficient on the management score typically increased (see Bloom and Van Reenen 2006).

\subsubsection{Obtaining Interviews with Managers}

The interview process took about fifty minutes on average, and was run from the London School of Economics. Overall, we obtained a high response rate of 54 percent, which was achieved through four steps.

- First, the interview was introduced as "a piece of work" ${ }^{15}$ without discussion of the firm's financial position or its company accounts, making it relatively uncontroversial for managers to participate. Interviewers did not discuss financials in the interviews, both to maximize the par-

13. Thanks to the interview team of Johannes Banner, Michael Bevan, Mehdi Boussebaa, Dinesh Cheryan, Alberic de Solere, Manish Mahajan, Simone Martin, Himanshu Pande, Jayesh Patel, and Marcus Thielking.

14. In particular, we found the scores were significantly higher for senior managers when interviews were conducted later in the week and/or earlier in the day. That is to say, scores were highest, on average, for senior managers on a Friday morning and lowest for junior managers on a Monday afternoon. By including information on these characteristics in our analysis, we explicitly controlled for these types of interview bias.

15. Words like "survey" or "research" should be avoided as these are used by switchboards to block market research calls. 
ticipation of firms and to ensure our interviewers were truly "blind" on the firm's financial position.

- Second, management questions were ordered to lead with the least controversial (shop-floor management) and finish with the most controversial (pay, promotions, and firings). The WLB questions were placed at the end of the interview to ensure the most candor in the response to this.

- Third, interviewers' performance was monitored, as was the proportion of interviews achieved, so they were persistent in chasing firms (the median number of contacts each interviewer had per interview was 6.4). The questions are also about practices within the firm that any plant manager can respond to, so there were potentially several managers per firm who could be contacted. ${ }^{16}$

- Fourth, written endorsement of the Bundesbank (in Germany) and the Treasury (in the United Kingdom), and a scheduled presentation to the Banque de France, helped demonstrate to managers this was an important exercise with official support.

\subsubsection{Sampling Frame and Additional Data}

Since our aim was to compare across countries we decided to focus on the manufacturing sector, where productivity is easier to measure than in the nonmanufacturing sector. We also focused on medium-sized firms, selecting a sample where employment ranged between fifty and 10,000 workers (with a median of 700). Very small firms have little publicly available data. Very large firms are likely to be more heterogeneous across plants, and it would be more difficult to get a picture of managerial performance in the firm as a whole from one or two plant interviews. We drew a sampling frame from each country to be representative of medium-sized manufacturing firms and then randomly chose the order of which firms to contact (see appendix B for details). We also excluded any clients of our partnering consultancy firm from our sampling frame. ${ }^{17}$

Comparing the responding firms with those in the sampling frame, we found no evidence that the responders were systematically different to the nonresponders on any of the performance measures. They were also statistically similar on all the other observables in our data set. The only exception was on size, where our firms were slightly larger than average than those in the sampling frame.

16. We found no significant correlation between the number, type, and time span of contacts before an interview is conducted and the management score. This suggests while different managers may respond differently to the interview proposition, this does not appear to be directly correlated with their responses or the average management practices of the firm.

17. This removed thirty-three firms out of our sampling frame of 1,353 firms. 


\subsubsection{Evaluating and Controlling for Potential Measurement Error}

To quantify possible measurement error in the WLB and management practice scores obtained using our survey tool, we performed repeat interviews on management practice data on sixty-four firms - contacting different managers in the firm, typically at different plants, using different interviewers. To the extent that our measures are truly picking up general company-wide practices these two scores should be correlated, while if our measures are driven by noise these should be independent.

Figure 1.4 plots the average firm-level management scores from the first interview against the second interview, from which we can see that they are highly correlated (correlation 0.734 with $p$-value 0.000 ). Furthermore, there is no obvious (or statistically significant) relationship between the degree of measurement error and the absolute score. That is to say, high and low scores appear to be as well measured as average scores, and firms that have high (or low) scores on the first interview tend to have high (or low) scores on the second interview. Thus, firms that score below two or above four on the 1 to 5 scale of composite management scores appear to be genuinely badly or well managed rather than extreme draws of sampling measurement error.

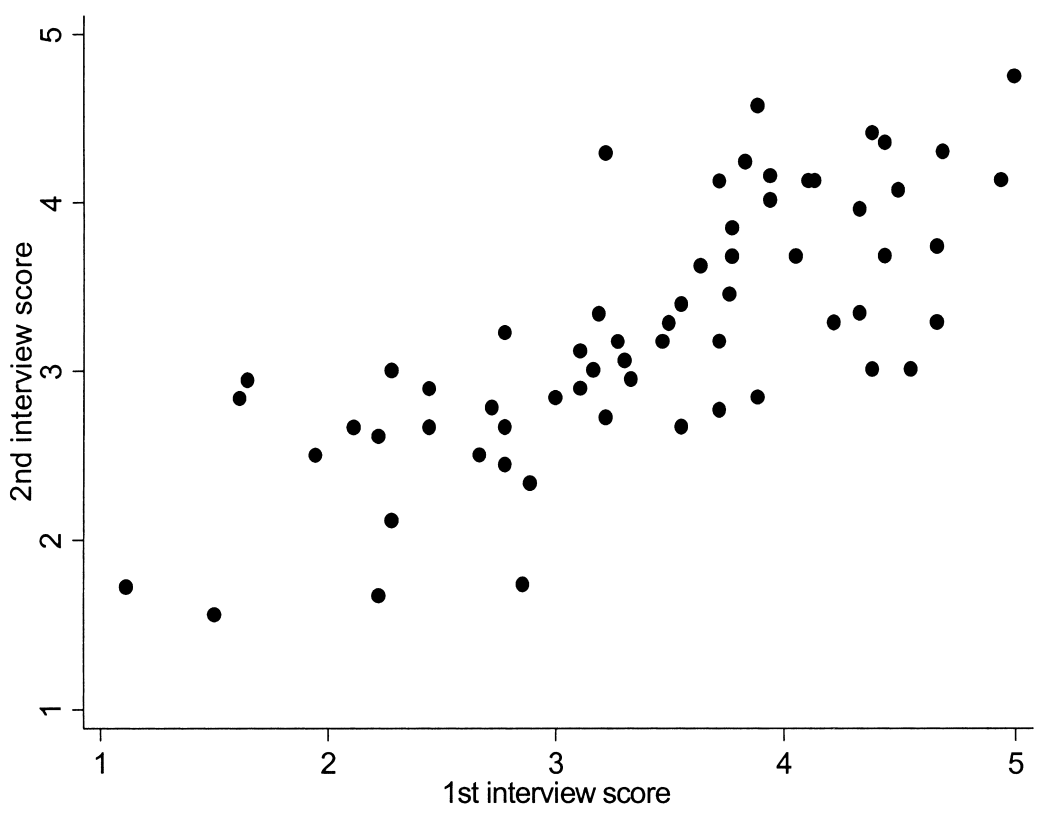

Fig. 1.4 The management scoring appears reliable

Note: Scores from sixty-four repeat interviews on the same firm with different managers and different interviewers. 


\subsubsection{Productivity and Competition Data}

Quantitative information on firm sales, employment, capital, materials, and so forth came from the company accounts and proxy statements, and was used to calculate firm level productivity. The details are provided in appendix B. To measure competition we follow Nickell (1996) and Aghion et al. (2005) in using three broad measures. The first measure is the degree of import penetration in the country by three-digit industry measured as the share of total imports over domestic production. This is constructed for the period 1995 to 1999 to remove any potential contemporaneous feedback. The second is the country by three-digit industry Lerner index of competition, which is ( 1 - profits/sales), calculated as the average across the entire firm level database (excluding each firm itself). ${ }^{18}$ Again, this is constructed for the period 1995 to 1999 to remove any potential contemporaneous feedback. The third measure of competition is the survey question on the number of competitors a firm faces (see appendix A, table 1A.2), valued zero for "no competitors," one for "less than 5 competitors," and two for " 5 or more competitors". ${ }^{19}$

\subsection{Results}

The first thing we look at is whether our key measures of WLB outcomes were correlated with the practices that we might expect to improve employee WLB. If this did not turn out to be true, we would suspect that the WLB outcome measure was not really reflecting the actual events on the ground but rather some other unobservable firm-specific characteristic.

\subsubsection{WLB Practices and WLB Outcomes}

Table 1.2 examines this issue by regressing the WLB outcome indicator on a number of variables that we would expect to be associated with better work-life balance. Reassuringly we find that all the associations are sensible.

Column (1) simply correlates WLB with average hours worked per week in the firm across all employees. An extra ten hours a week worked is associated with a 0.4 points lower WLB score (about 12 percent lower than the mean of 3.21). This association is significant at the 5 percent level. In the second column we control for four country dummies, firm size, whether the firm is publicly listed, and firm age. With the exception of the country dummies ${ }^{20}$

18. Note that in constructing this we draw on firms in the population database, not just those in the survey.

19. This question has been used by inter alia Nickell (1996) and Stewart (1990).

20. The pattern of the country dummies suggests that conditional on other factors, Germans report the worst work-life balance and Americans report the best work-life balance. It is difficult to interpret these results, however, as the WLB question is relative to the industry 


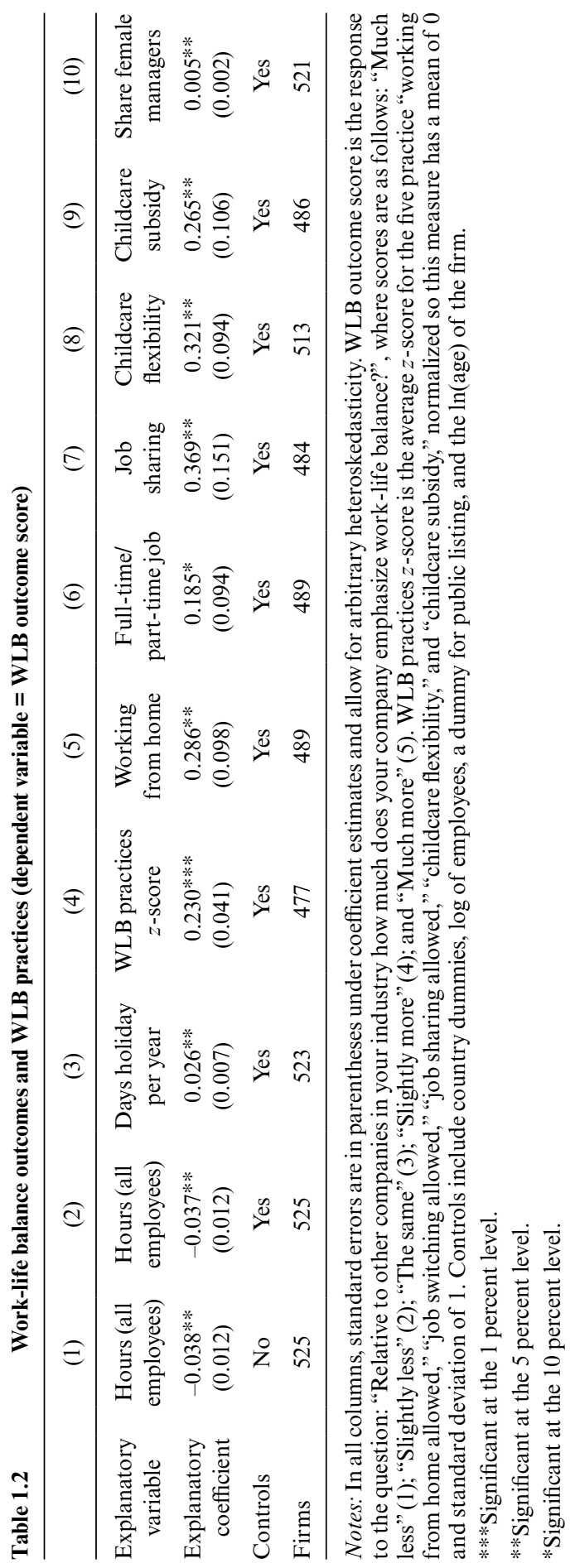


and firm size ${ }^{21}$ all other variables are insignificant. The coefficient on managerial hours stays essentially the same. ${ }^{22}$ Column (3) includes the number of days' holiday per year-more holidays are associated with a higher WLB score.

We next consider the composite WLB practices $z$-score (the average $z$-score across the five practices - working from home, job switching, job sharing, childcare flexibility, and childcare subsidy). When we include this WLB practice score in the regression in column (4), the variable is positive and highly significant. The next five columns show the correlation of WLB with each of the five practices individually.

Firms that are flexible and allow some working from home (column [5]), job switching (column [6]), and job sharing (column [7]) also have higher reported WLB outcomes. The next two columns show that firms who have more family-friendly policies with regard to allowing flexibility for employees to take time off for children ${ }^{23}$ or offer childcare subsidies also score more highly on WLB. All of these correlations are significant and consistent with the notion that the WLB outcome measure reflects something real about the WLB policies in the firm.

The final column includes the proportion of female managers in the regression. Firms who have a greater proportion of female managers are also more likely to report a higher WLB outcome. This correlation is specifically related to the proportion of female managers, not females in the workplace as a whole. The share of females in nonmanagerial positions is not correlated with WLB. This suggests that the correlation does not simply arise from the fact that women are more or less attracted to different firms. More likely is some combination of: (a) in firms with more female managers there is greater decisionmaking support for improved WLB because the balance of power is more with women; and (b) female managers are attracted to firms with better WLB.

\subsubsection{Work-life Balance and Management}

Table 1.3 examines the correlation between WLB and our composite measure of good management described in the previous section. In previous

average so this implicitly removes the country effect if managers compare themselves to other firms in the same sector in the same country. The systematically lower score in Germany could reflect a "more negative" cultural bias in answering these questions.

21. Firm size is always strongly correlated with WLB, for example in column 2 of table 1.2 the coefficient (standard error) on log of employees is 0.104 (0.036), respectively.

22. If we split total hours into average hours worked by managers and average hours worked by nonmanagers both variables are negatively related to WLB at the 10 percent significance level or higher, suggesting WLB is related to the hours worked by both workers and managers.

23. Response to the question "If an employee needed to take a day off at short notice due to childcare problems or their child was sick how do they generally do this?", where this variable was ordered conceptually as: $1=$ Not allowed; $2=$ Allowed but unpaid; and $3=$ Allowed and paid. Hence, we allocated the responses to the scores as follows: A score of 1 for "Not Allowed" or "Never been asked;" a score of 2 for "Take as leave without pay" or "Take time off but make it up later;" and a score of 3 for "Take as annual leave" or "Take as sick leave." 


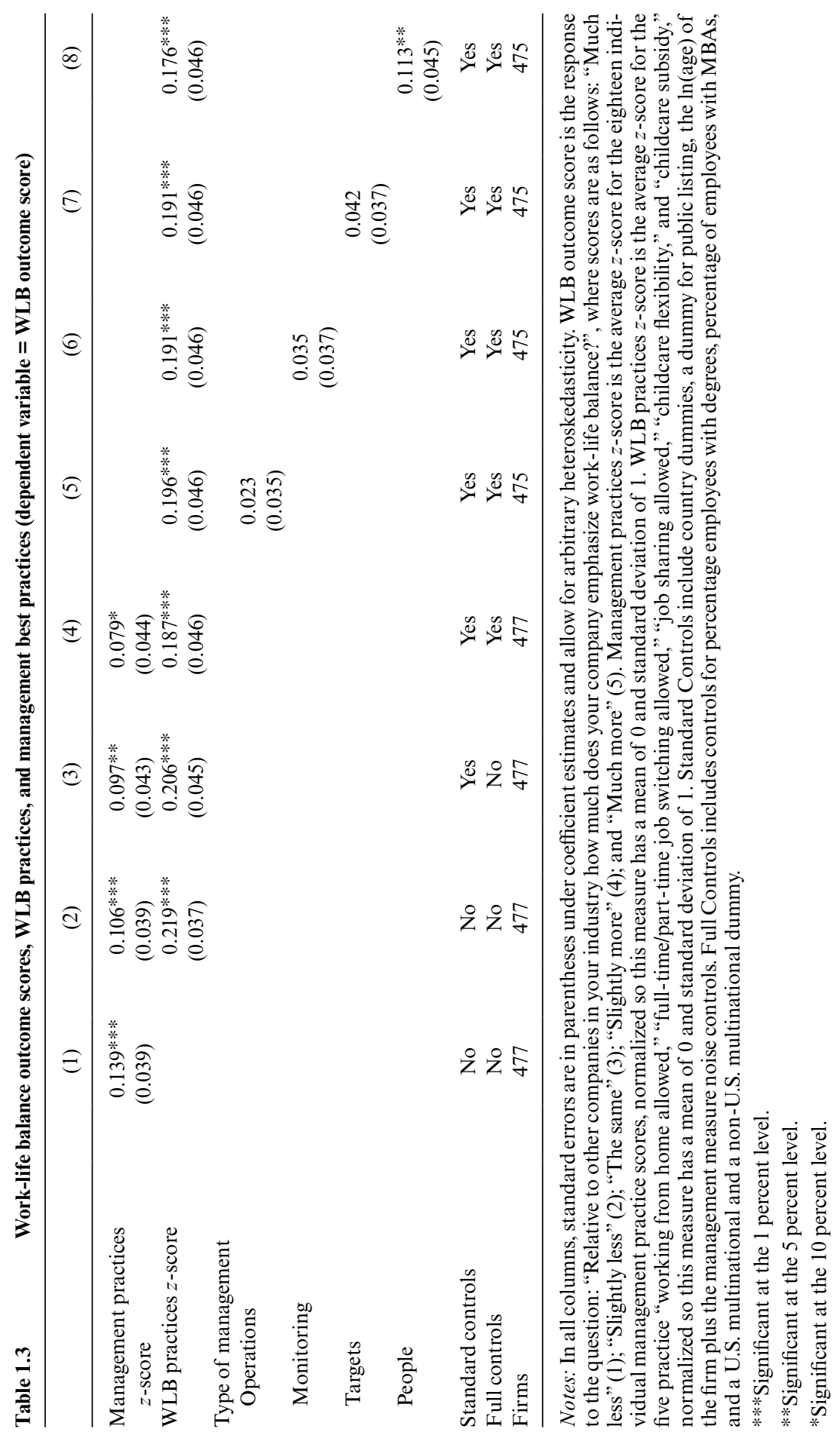


work, we have found this a reliable metric of the overall degree of managerial quality in the firm and the management score is strongly correlated with superior firm performance. Is it the case that firms who adopt these better "Anglo-Saxon" management practices do so at the expense of employees' work-life balance?

In the first column of table 1.3, we regress our WLB outcome measure on the average management score and nothing else. There is a strong positive and significant correlation between the two variables. The second column then includes the composite score of the WLB practices. This is also positive and highly significant. The third column includes the "standard" vector of controls (firm size, firm age, country dummies, listing status, and controls for measurement error in the survey such as interviewer fixed effects). Both variables remain positive and significant. The fourth column includes skills and multinational status as additional controls. The skills measure - the proportion of workers with degrees - is significant at the 5 percent level. Hence, firms with higher skilled employees also tend to have better work-life balance practices. After including these additional controls, the management coefficient falls further and is now only significant at the 10 percent level. Hence, while WLB practices play a strong role in influencing the WLB outcomes, management practices per se play only a weak role in influencing these, after including a full set of control variables.

We then disaggregate our management measure into four componentsoperations, monitoring, targets, and people management (incentives). Interestingly, the WLB measure is correlated with each of these positively when entered individually into the regression (columns [5] through [8]), but only people management/incentives is significant at the 5 percent level. Thus, it appears that while WLB practices are linked with good management, this is much stronger for people management practices than other types of management practices.

\subsubsection{Competition, Work-Life Balance, and Management}

Having established the correlations of WLB with several factors, we now turn to the key hypotheses on competition and productivity. Our previous research found that tougher product market competition drives higher productivity ${ }^{24}$ and at least part of this seems to work through improving management practices (Bloom and Van Reenen 2006). Nevertheless, does competition damage work-life balance?

Table 1.4 examines this question in detail. We measure competition by the degree of openness to trade (columns [1] and [2]), the degree of "excess profit" in the industry (columns [3] and [4]), or simply the number of competitors (columns [4] and [5]). In column (1) import competition is weakly

24. On the relationship between productivity and competition see also inter alia Nickell (1996) and Syverson (2004a, 2004b). 
Work-life balance outcomes and product market competition (OLS estimation, dependent variable $=$ WLB outcome score)

\begin{tabular}{lcccccc}
\hline & $(1)$ & $(2)$ & $(3)$ & $(4)$ & $(5)$ & $(6)$ \\
\hline $\begin{array}{l}\text { Import penetration } \\
\quad \text { (5-year lagged) }\end{array}$ & $0.147^{*}$ & 0.073 & & & & \\
$\begin{array}{l}\text { Lerner index of competition } \\
\quad(0.079)\end{array}$ & $(0.145)$ & & & & \\
$\quad$ Number lagged) & & & 0.463 & 0.306 & & \\
& & & $(0.858)$ & $(1.118)$ & & \\
Firms & & & & & 0.009 & -0.000 \\
Country controls & 492 & 492 & 486 & 486 & 524 & 530 \\
Full controls & Yes & Yes & Yes & Yes & Yes & Yes \\
\hline
\end{tabular}

Notes: Coefficients from OLS regressions with standard errors in parentheses (robust to arbitrary heteroskedasticity and clustered by country $X$ industry pair); single cross-section. Country controls includes four country dummies. Full controls includes $\ln$ (firm size), $\ln$ (firm age), a dummy for being listed, the share of workforce with degrees, the share of workforce with MBAs, a dummy for being consolidated, and the survey noise controls. Import Penetration $=\ln$ (Import/ Production) in every country industry pair. Average over 1995 to 1999 used. Lerner index of competition constructed, as in Aghion et al (2005), as the mean of (1 - profit/sales) in the entire database (excluding the firm itself) for every country industry pair. Number of competitors constructed from the response to the survey question on number of competitors, and is coded as 0 for "none" ( 1 percent of responses), 1 for "less than 5 " (51 percent of responses), and 2 for " 5 or more" (48 percent of responses). Columns (4) through (6) include the "noise controls" of column (2) in table 1A.2 (seventeen interviewer dummies, the seniority, gender, tenure, and number of countries worked in of the manager who responded, the day of the week the interview was conducted, the time of the day the interview was conducted, the duration of the interviews, and an indicator of the reliability of the information as coded by the interviewer).

*** Significant at the 1 percent level.

**Significant at the 5 percent level.

*Significant at the 10 percent level.

and positively associated with better WLB, but this association disappears when we include the additional controls in column (2). A similar picture emerges in the other columns - competition is essentially uncorrelated with WLB outcomes. We conclude that although competition seems to improve management, it does not seem to reduce WLB.

We also estimated the relationship between competition and the WLB practices examined later in section 1.4.4 - working from home flexibility, job switching flexibility, flexibility for childcare time off, and childcare subsidies - and found no significant relationships. We could not find any relationship between average hours worked per week or days holidays per year and competition. So we confirm the earlier conclusion that although competition seems to improve management, it does not seem to be associated with worse WLB outcomes or practices. While higher competition appears to increase management practices by removing the worst managed/least productive firms from the market it does not seem to affect WLB. This is presumably because - as we show in the next section - WLB practices and 
Table 1.5

Work-life balance practices are unrelated to productivity (All countries, OLS estimation, dependent variable $=\mathrm{Ln}\left(\right.$ Sales $\left._{\mathrm{it}}\right)$ )

\begin{tabular}{|c|c|c|c|}
\hline & (1) & (2) & (3) \\
\hline $\begin{array}{l}\text { WLB practices } \\
z \text {-score }\end{array}$ & $\begin{array}{l}0.048 * * \\
(0.023)\end{array}$ & $\begin{array}{c}0.034 \\
(0.023)\end{array}$ & $\begin{array}{l}-0.005 \\
(0.018)\end{array}$ \\
\hline Management $z$-score & & $\begin{array}{l}0.064 * * * \\
(0.023)\end{array}$ & $\begin{array}{l}0.038^{* * * *} \\
(0.015)\end{array}$ \\
\hline $\operatorname{Ln}\left(\right.$ Labor $\left._{\mathrm{it}}\right)$ & $\begin{array}{l}0.983 * * * \\
(0.018)\end{array}$ & $\begin{array}{l}0.978^{* * * *} \\
(0.018)\end{array}$ & $\begin{array}{l}0.500 * * * \\
(0.032)\end{array}$ \\
\hline $\operatorname{Ln}\left(\right.$ Capital $\left._{\mathrm{it}}\right)$ & & & $\begin{array}{l}0.122 * * * \\
(0.027)\end{array}$ \\
\hline $\operatorname{Ln}\left(\right.$ Materials $\left._{\mathrm{it}}\right)$ & & & $\begin{array}{l}0.370^{* * * *} \\
(0.032)\end{array}$ \\
\hline Basic Controls & Yes & Yes & Yes \\
\hline Full controls & No & No & Yes \\
\hline Firms & 481 & 481 & 481 \\
\hline
\end{tabular}

Notes: In all columns, standard errors are in parentheses under coefficient estimates and allow for arbitrary heteroskedasticity. Basic controls include country and industry dummies, $\log$ (firm age), public listing, and consolidated dummy. Full controls include industry dummies, $\log$ (firm age), public listing, percent of workforce with degrees, percent of employees with MBAs, U.S. multinational dummy and non-U.S. multinational dummy. Management practices $z$-score is the average $z$-score for the eighteen individual management practice scores, normalized so this measure has a mean of 0 and standard deviation of 1 . WLB practices $z$ score is the average $z$-score for the five practice "working from home allowed," "full-time/ part-time job switching allowed," "job sharing allowed," "childcare flexibility," and "childcare subsidy," normalized so this measure has a mean of 0 and standard deviation of 1 .

Source: Bloom, Kretschmer, and Van Reenen (2008).

***Significant at the 1 percent level.

**Significant at the 5 percent level.

*Significant at the 10 percent level.

productivity are essentially unrelated, so that the selection effects of competition have no bearing on typical WLB practices.

\subsubsection{Productivity, Work-Life Balance, and Management}

Perhaps the most important issue is the association of WLB with productivity. We address this issue in table 1.5, which shows the results from simple production functions. We must always remember the caveat that these are associations and we cannot infer causality. ${ }^{25}$ The dependent variable is the $\log$ of real sales and because we control for the factor inputs (labor, capital, and materials) the coefficient on WLB practices should be interpreted as the association with Total Factor (or revenue) Productivity (TFP). These variables are taken from company accounts as measured by the number of employees for labor, the net-tangible fixed assets for capital, and the reported materials

25 . We are currently running field experiments in India to randomize improvement in management practices across firms to evaluate its causal impact on energy use. 
costs. For labor we also control for the average hours worked in the firm. Of course one issue is the measurement error around these inputs that could lead to attenuation, which could potentially bias the results, particularly if this was correlated with the WLB measures (e.g., Siegel 1997).

Column (1) of table 1.5 reports the first specification that also includes country and industry dummies and basic controls (firm age, listing status, and a consolidation dummy). The association of WLB and productivity is positive and significant at the 5 percent level. This is the kind of regression highlighted in the Human Resource Management literature that is often used to justify policies to introduce better WLB practices.

Column (2) of table 1.5 simply conditions on our management $z$-score, which enters the production function with a positive and highly significant coefficient. The WLB practices variable, by contrast, falls in magnitude and is no longer significant at even the 10 percent level. When we condition on a wider set of controls in the next column (skills, multinational status, listing, and firm age), the management variable remains positive and significant (see Bloom and Van Reenen 2006) but the WLB practices variable is now negative, albeit completely insignificant.

Table 1.5 suggests that the significant association of WLB with productivity is spurious and arises because WLB is correlated with an important omitted variable — good management. Firms with better management practices will tend to have both higher productivity and better work-life balance. This gives rise (in column [1]) to the mistaken impression that better WLB causes higher productivity.

\subsubsection{Multinationals, Work-Life Balance, and Management}

Finally, in table 1.6 we examine some of the cross-country differences in WLB practices and management practices. The first column simply regresses the composite WLB practice measure on the country dummies (the United States is the omitted base). It is clear that the United States has less generous WLB practices than the European countries and France has more generous WLB practices than the United Kingdom or Germany. The second column includes dummy variables indicating whether for the European based firms they are a U.S. multinational or a non-U.S. multinational (European domestic firms are the omitted base). ${ }^{26}$ The WLB does not seem worse in U.S. multinationals located overseas as indicated by the insignificant variable on the dummy than on the local domestic firms (and indeed the non-U.S. multinational dummy). This does not change when we condition on the more extended covariate set in column (3). Therefore, U.S. multinationals in Europe appear to adopt local work-life balance practices.

In contrast, columns (4) to (6) show that U.S. multinationals in Europe

26. Our U.S. firms are all publicly traded so we have no multinational subsidiaries in the U.S. Hence, these regressions compare between different types of European firms. Restricting the estimates to only European firms thus does not change the point estimates on the U.S. and non-U.S. multinationals. 
Table 1.6

Work-life balance and management practices in domestic and multinational firms (All countries, OLS estimation)

\begin{tabular}{|c|c|c|c|c|c|c|}
\hline & \multicolumn{3}{|c|}{$\begin{array}{c}\text { Dependent variable }=\text { WLB } \\
\text { practices } z \text {-score }\end{array}$} & \multicolumn{3}{|c|}{$\begin{array}{c}\text { Dependent variable }=\text { Management } \\
\text { practices } z \text {-score }\end{array}$} \\
\hline & (1) & (2) & (3) & (4) & (5) & (6) \\
\hline \multicolumn{7}{|l|}{ Baseline is U.S. } \\
\hline Country is France & $\begin{array}{l}1.066 * * * \\
(0.0115)\end{array}$ & $\begin{array}{l}1.052^{* * *} \\
(0.117)\end{array}$ & $\begin{array}{l}1.284^{* * *} \\
(0.179)\end{array}$ & $\begin{array}{l}-0.270^{* * *} \\
(0.103)\end{array}$ & $\begin{array}{l}-0.302 * * * \\
(0.104)\end{array}$ & $\begin{array}{l}-0.091 \\
(0.156)\end{array}$ \\
\hline Country is Germany & $\begin{array}{l}0.306^{* * *} \\
(0.109)\end{array}$ & $\begin{array}{l}0.288^{* * *} \\
(0.111)\end{array}$ & $\begin{array}{l}0.368^{* *} \\
(0.155)\end{array}$ & $\begin{array}{l}-0.093 \\
(0.098)\end{array}$ & $\begin{array}{l}-.0142 \\
(0.099)\end{array}$ & $\begin{array}{l}-0.067 \\
(0.156)\end{array}$ \\
\hline Country is UK & $\begin{array}{l}0.336^{* * *} \\
(0.120)\end{array}$ & $\begin{array}{l}0.320^{* * *} \\
(0.121)\end{array}$ & $\begin{array}{l}0.439 * * * \\
(0.166)\end{array}$ & $\begin{array}{l}-0.359 * * * \\
(0.099)\end{array}$ & $\begin{array}{l}-0.396 * * * \\
(0.100)\end{array}$ & $\begin{array}{l}-0.290^{* *} \\
(0.138)\end{array}$ \\
\hline $\begin{array}{l}\text { U.S. Multinational in } \\
\text { (Europe) }\end{array}$ & & $\begin{array}{c}0.229 \\
(0.255)\end{array}$ & $\begin{array}{l}-0.059 \\
(0.215)\end{array}$ & & $\begin{array}{l}0.828^{* * * *} \\
(0.220)\end{array}$ & $\begin{array}{l}0.679 * * * \\
(0.242)\end{array}$ \\
\hline $\begin{array}{l}\text { Non-U.S. multi- } \\
\text { national (in Europe) }\end{array}$ & & $\begin{array}{c}0.149 \\
(0.286)\end{array}$ & $\begin{array}{c}0.059 \\
(0.291)\end{array}$ & & $\begin{array}{c}0.077 \\
(0.251)\end{array}$ & $\begin{array}{l}-0.223 \\
(0.316)\end{array}$ \\
\hline Basic controls & No & No & Yes & No & No & Yes \\
\hline Firms & 492 & 492 & 492 & 732 & 732 & 732 \\
\hline
\end{tabular}

Notes: In all columns, standard errors are in parentheses under coefficient estimates and allow for arbitrary heteroskedasticity. Basic controls include country and industry dummies, $\log$ (firm age), public listing, percent of workforce with degrees, and percent of employees with MBAs. Management practices $z$-score is the average $z$-score for the eighteen individual management practice scores, normalized so this measure has a mean of 0 and standard deviation of 1. WLB practices $z$-score is the average $z$-score for the five practice "working from home allowed," "full-time/part-time job switching allowed," "job sharing allowed," "childcare flexibility," and "childcare subsidy," normalized so this measure has a mean of 0 and standard deviation of 1 .

*** Significant at the 1 percent level.

** Significant at the 5 percent level.

*Significant at the 10 percent level.

bring over their better U.S. management practices. So in column (4) we see that on management practices the United Kingdom and France have significantly worse management practices than the United States and Germany. Including the multinational controls in column (5) we see when U.S. multinationals are located in Europe they appear to have significantly better management practices than equivalent non-U.S. multinationals and domestic firms (column [5]). In column (6), we see this result is robust to including additional covariates.

An interpretation of table 1.6 is that U.S. firms in general have better management practices but worse WLB policies. There are many complex reasons for these patterns. For example, although competition appears to be a reason for better U.S. management practices it cannot seem to explain its worse WLB outcomes as we showed that competition was unrelated to WLB in table 1.4. What is clear is that although U.S. firms appear to be able to transport their better management practices to Europe (column [6]), they do not transfer their worse WLB practices to Europe (column [3]). One rationale for this could be that European regulations require U.S. multinationals 
based in Europe to adopt these more worker-friendly practices. However, the work-life balance practices we measure-working from home, jobsharing, switching from full- to part-time, childcare flexibility, and childcare subsidies - are typically not directly regulated in Europe. Thus, our belief is that social norms explain much of this localization by U.S. multinationals, with this an area of ongoing research.

\subsection{Conclusions}

A debate is raging all over the developed world about quality of work issues. As unemployment has fallen in the United States and United Kingdom, attention has focused more on the quality rather than quantity of jobs. This has sharpened as women's participation has risen and issues of worklife balance and family-friendly policies have risen up the political agenda. This chapter has tried to shed some empirical light on these debates.

We characterized two opposing views of globalization, entitled the pessimistic and the optimistic view. The pessimists argue that "savage neoliberalism" encapsulated by tougher product market competition, globalization, and "Anglo-Saxon" managerial policies are undesirable. Although these forces will raise productivity, they come at the expense of misery for workers in the form of poor work-life balance (long hours, job insecurity, and intense and unsatisfying work). The optimistic Human Resource Management literature argues that better work-life balance will, in fact, improve productivity (and even profitability) and employers are mistakenly failing to treat their workers as assets and implement better work-life balance policies.

We find evidence for a hybrid view between these two extremes. Using originally collected data, we show that we have a useful firm specific measure of WLB. The pessimists' argument that "Anglo-Saxon" management practices are negatively associated with worse WLB is rejected - there is a positive association as suggested by the optimists. Similarly, the pessimists' theory that competition is inevitably bad for workers' WLB is also rejected: there is no significantly negative relationship. Larger firms - which are typically more globalized - also have better WLB practices on average. However, the view that WLB will improve productivity is also rejected: there is no relationship between productivity and WLB once we control for good management. Neither is there support for the pessimists' prediction that WLB is negatively associated with productivity.

Finally, looking at U.S. multinationals based in Europe we find an intriguing result that these firms appear to bring over their superior U.S. management practices with them to Europe but then adopt more worker-friendly European work-life balance practices. Why U.S. firms internationalize their management practices but localize their work-life balance practices appears to be due to a combination of regulations and social norms, an area of ongoing research. 


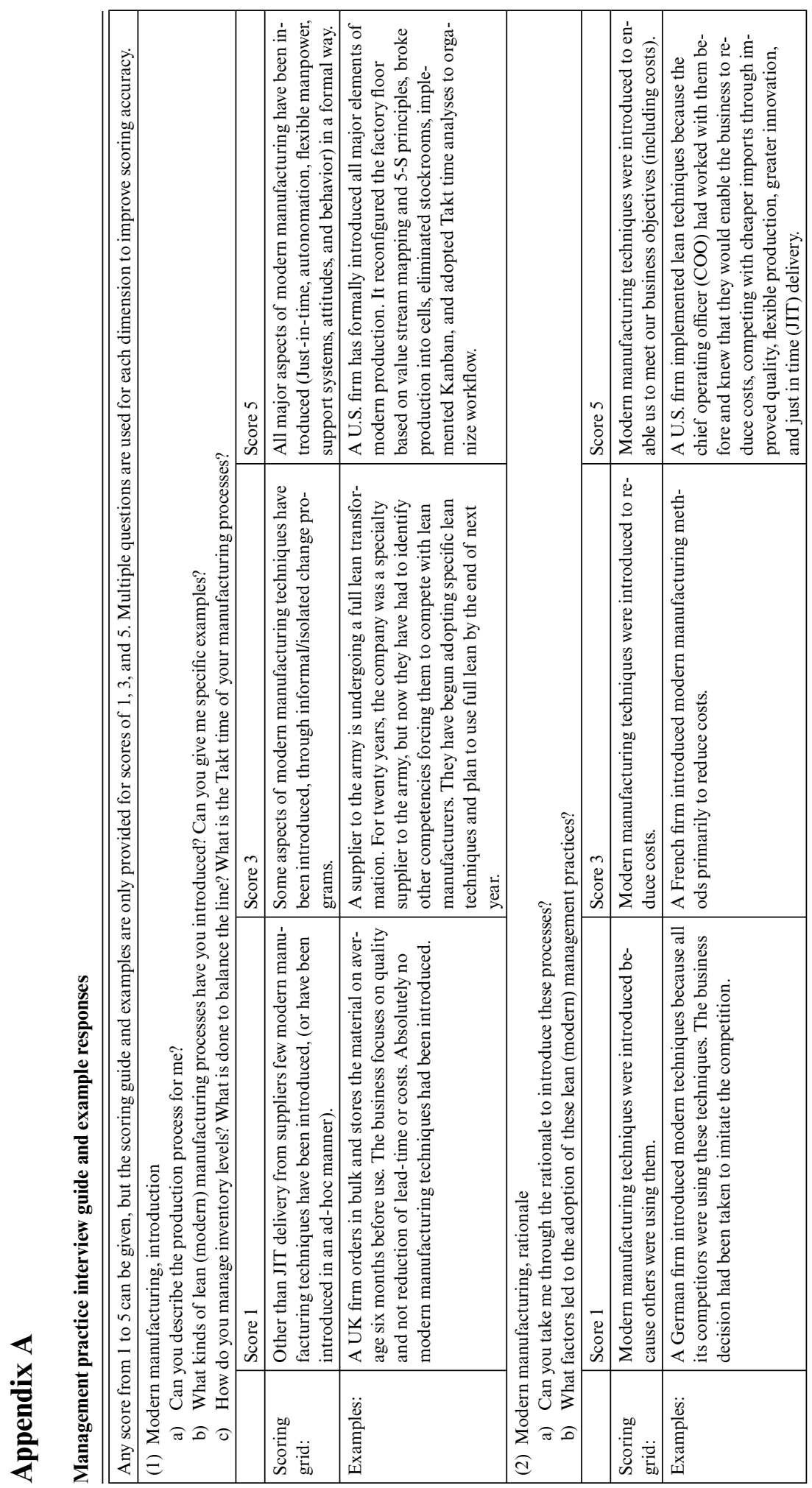




\begin{tabular}{|c|c|c|c|c|c|c|c|}
\hline & \begin{tabular}{|c|}
$n$ \\
0 \\
0 \\
0 \\
$n$ \\
\\
\end{tabular} & 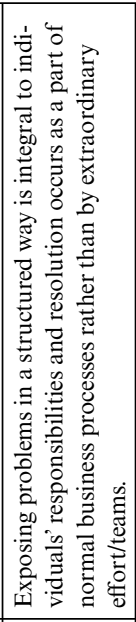 & 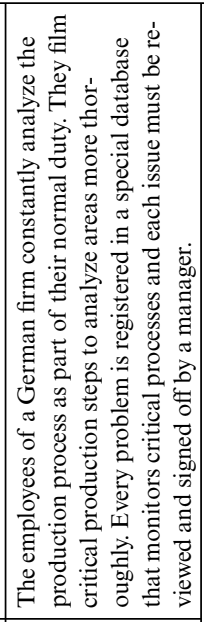 & $\Xi$ & 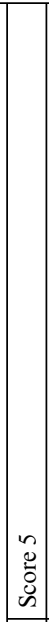 & 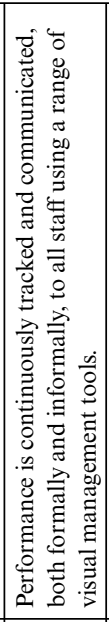 & 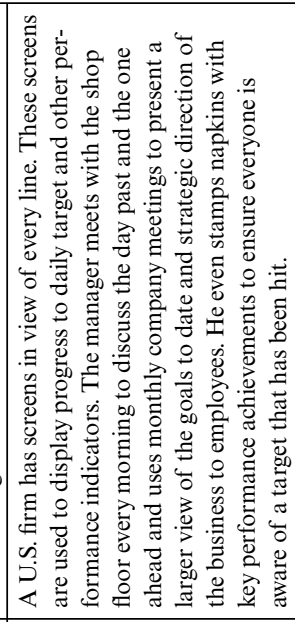 \\
\hline$\frac{\tilde{I}}{\mathrm{~g}}$ & \begin{tabular}{|c|} 
\\
0 \\
$\vdots$ \\
0 \\
$n$ \\
\end{tabular} & 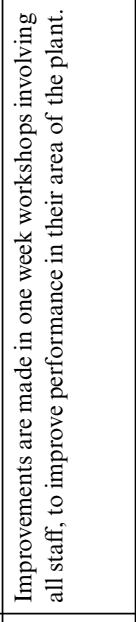 & 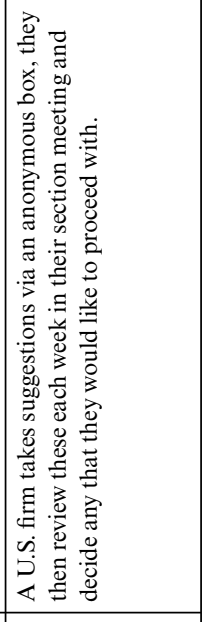 & 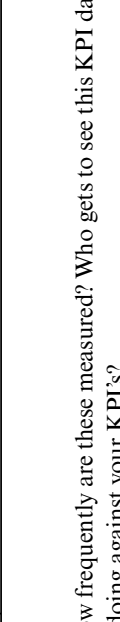 & 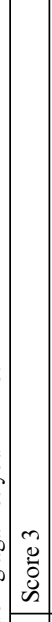 & 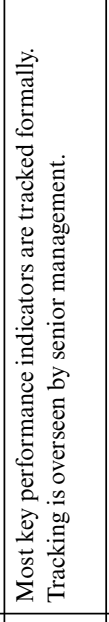 & 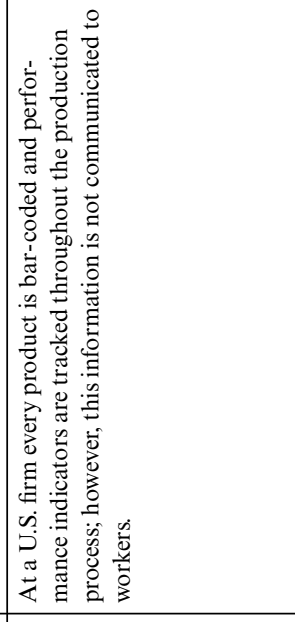 \\
\hline 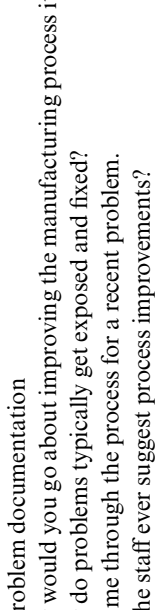 & \begin{tabular}{|l|}
$\overrightarrow{0}$ \\
$\overline{0}$ \\
$\tilde{u}$ \\
\end{tabular} & 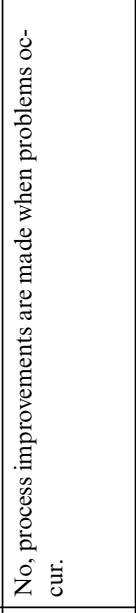 & 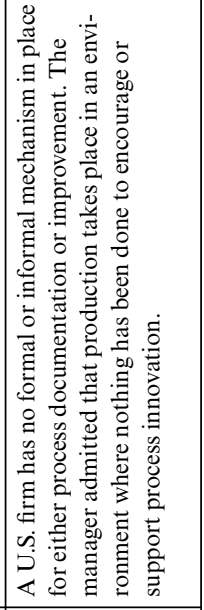 & 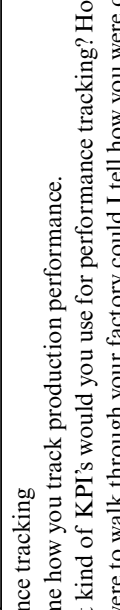 & 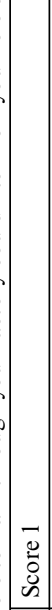 & 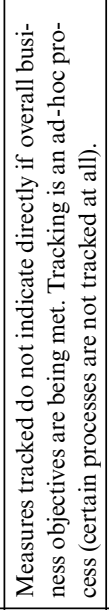 & 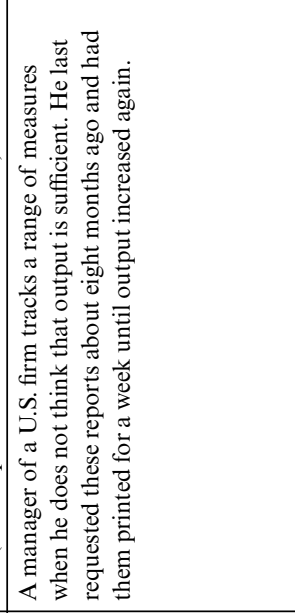 \\
\hline 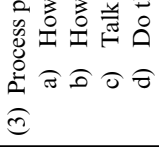 & & 总 & 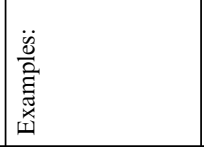 & 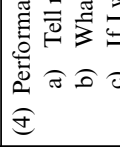 & & 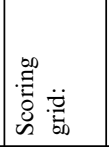 & 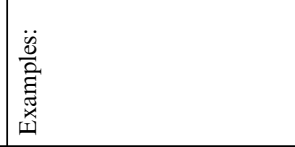 \\
\hline
\end{tabular}




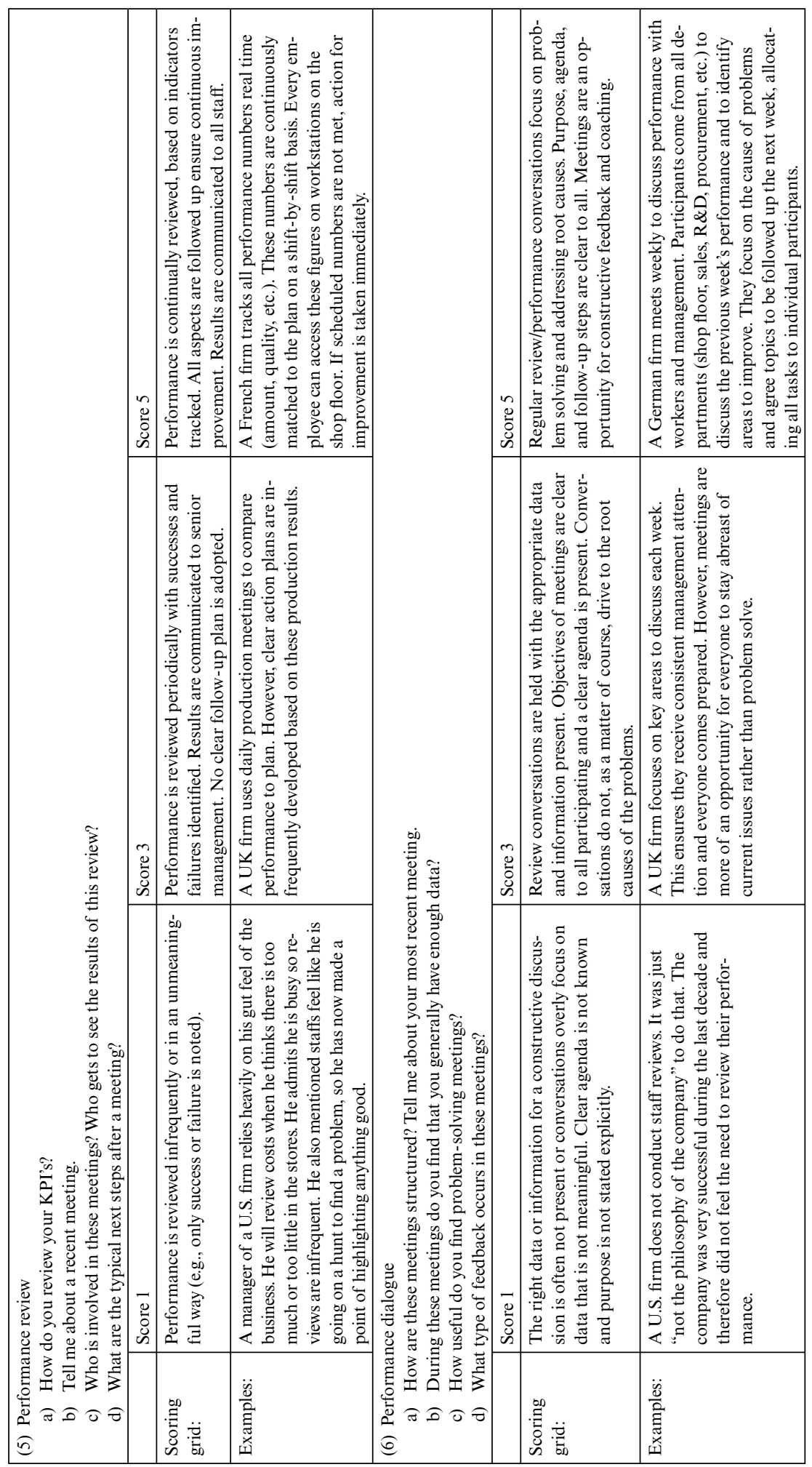




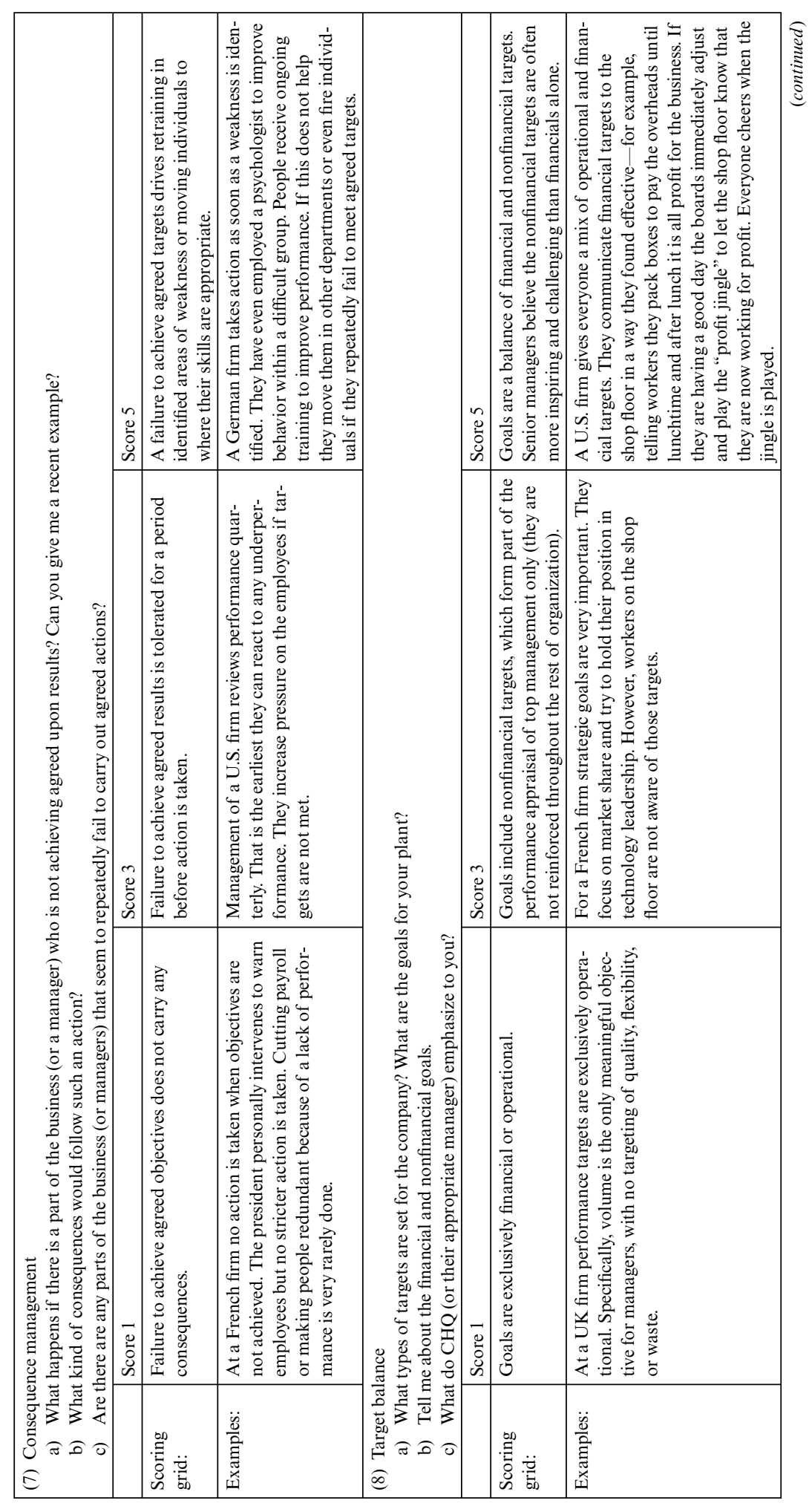




\begin{tabular}{|c|c|c|c|c|c|c|c|}
\hline & \begin{tabular}{|c|}
$n$ \\
0 \\
0 \\
0 \\
$n$ \\
$n$
\end{tabular} & 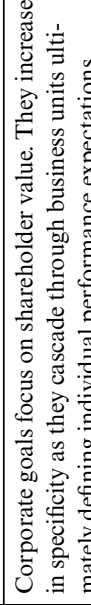 & 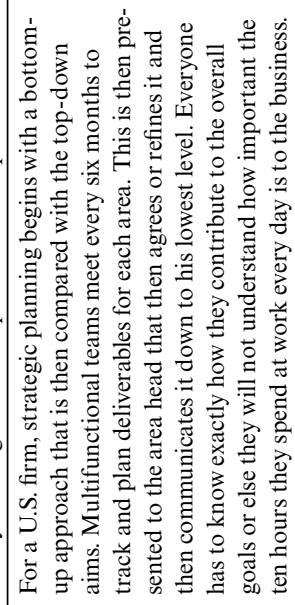 & & 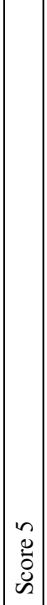 & 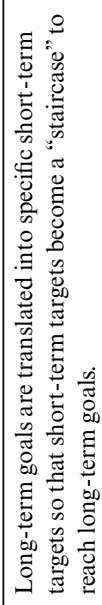 & 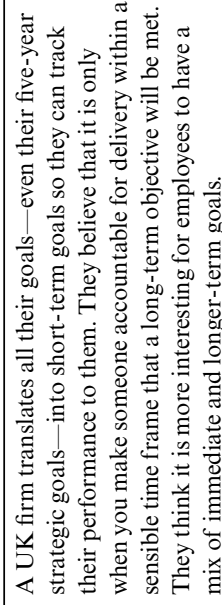 \\
\hline 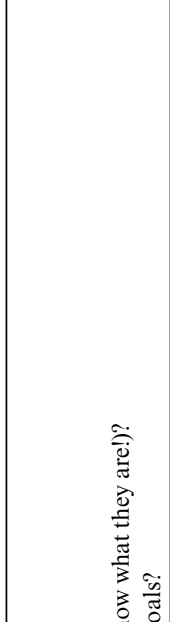 & $\begin{array}{l}0 \\
0 \\
0 \\
\tilde{b} \\
n\end{array}$ & 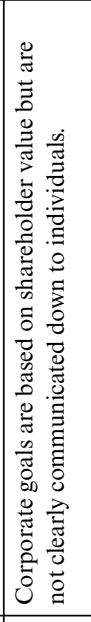 & 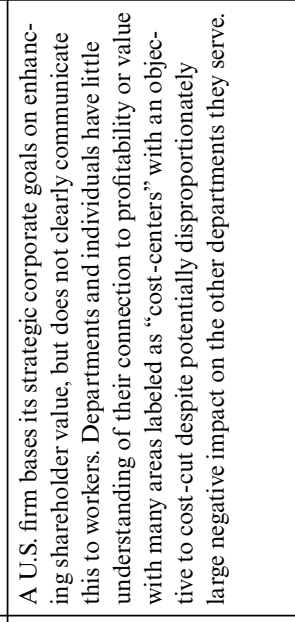 & $\frac{\tilde{m}}{\tilde{D}}$ & \begin{tabular}{|c|} 
\\
$\tilde{J}$ \\
$\tilde{b}$ \\
$\tilde{n}$ \\
\end{tabular} & 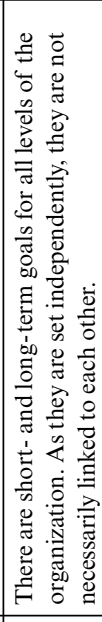 & 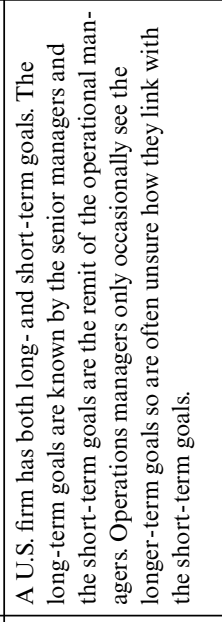 \\
\hline 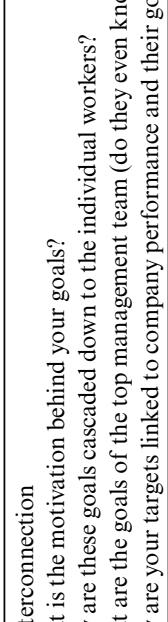 & 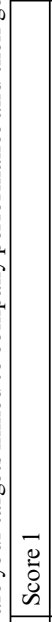 & 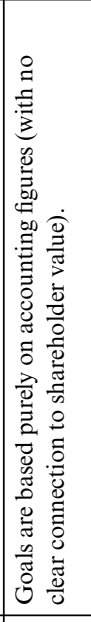 & 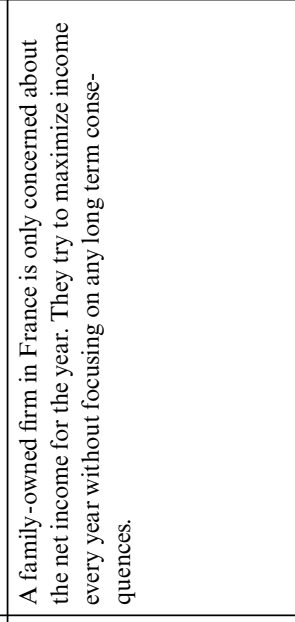 & 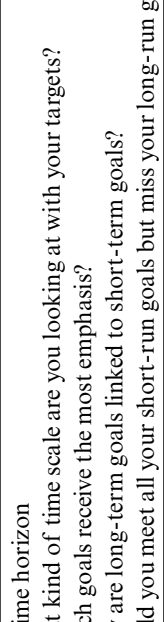 & $\begin{array}{l}\overrightarrow{0} \\
\overline{0} \\
\tilde{n} \\
\tilde{n}\end{array}$ & 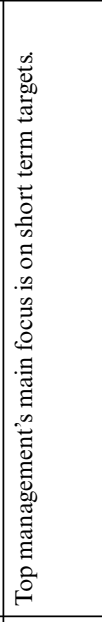 & 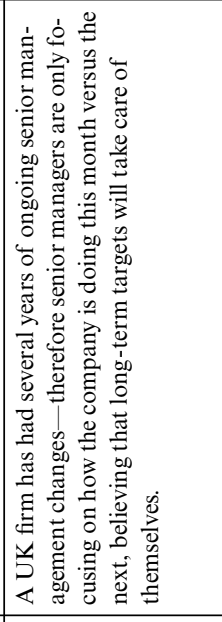 \\
\hline 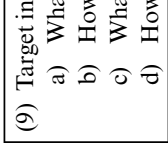 & & 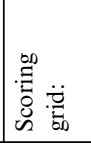 & 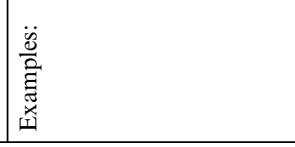 & 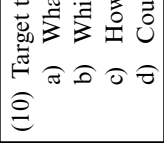 & & 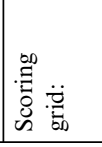 & 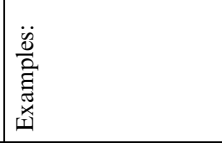 \\
\hline
\end{tabular}




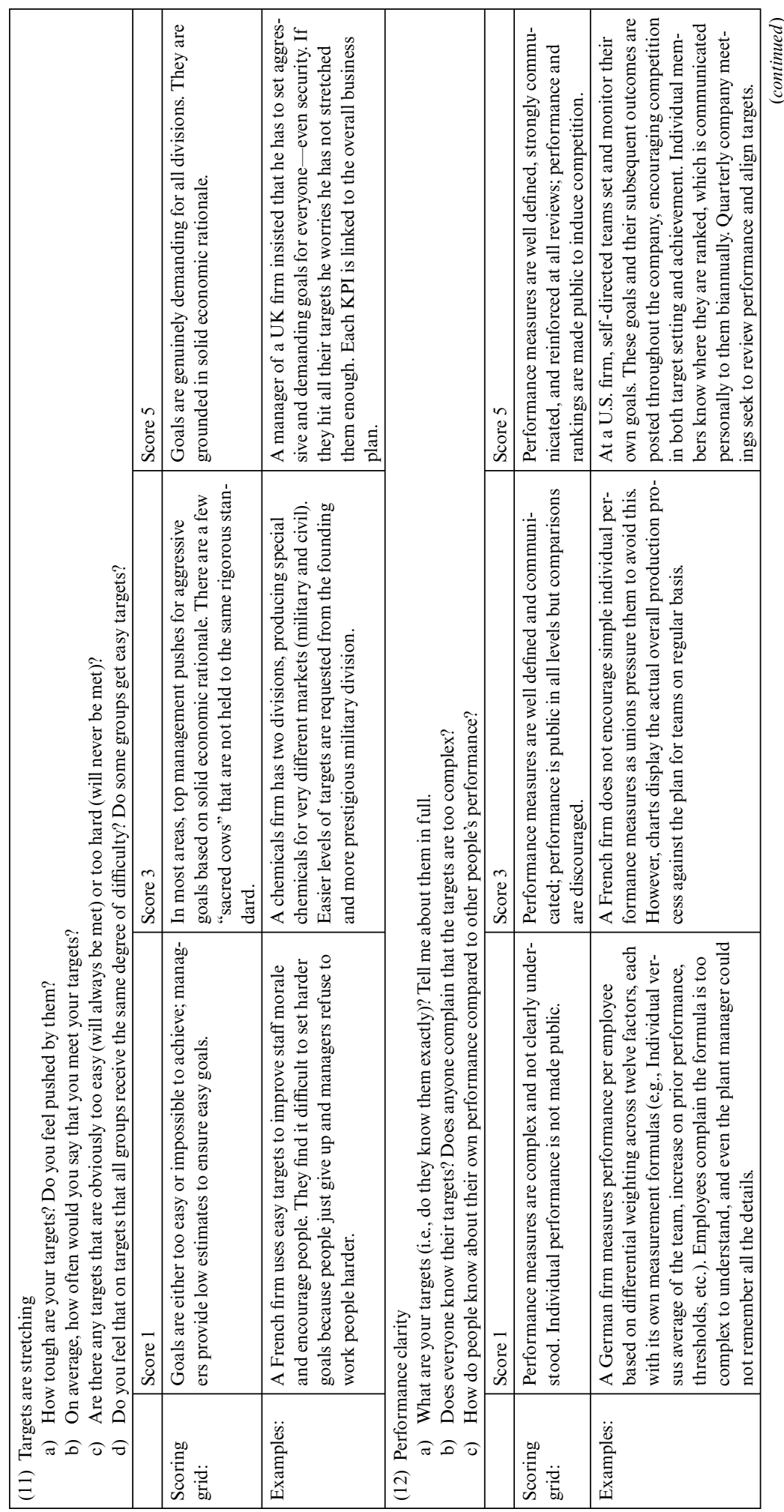




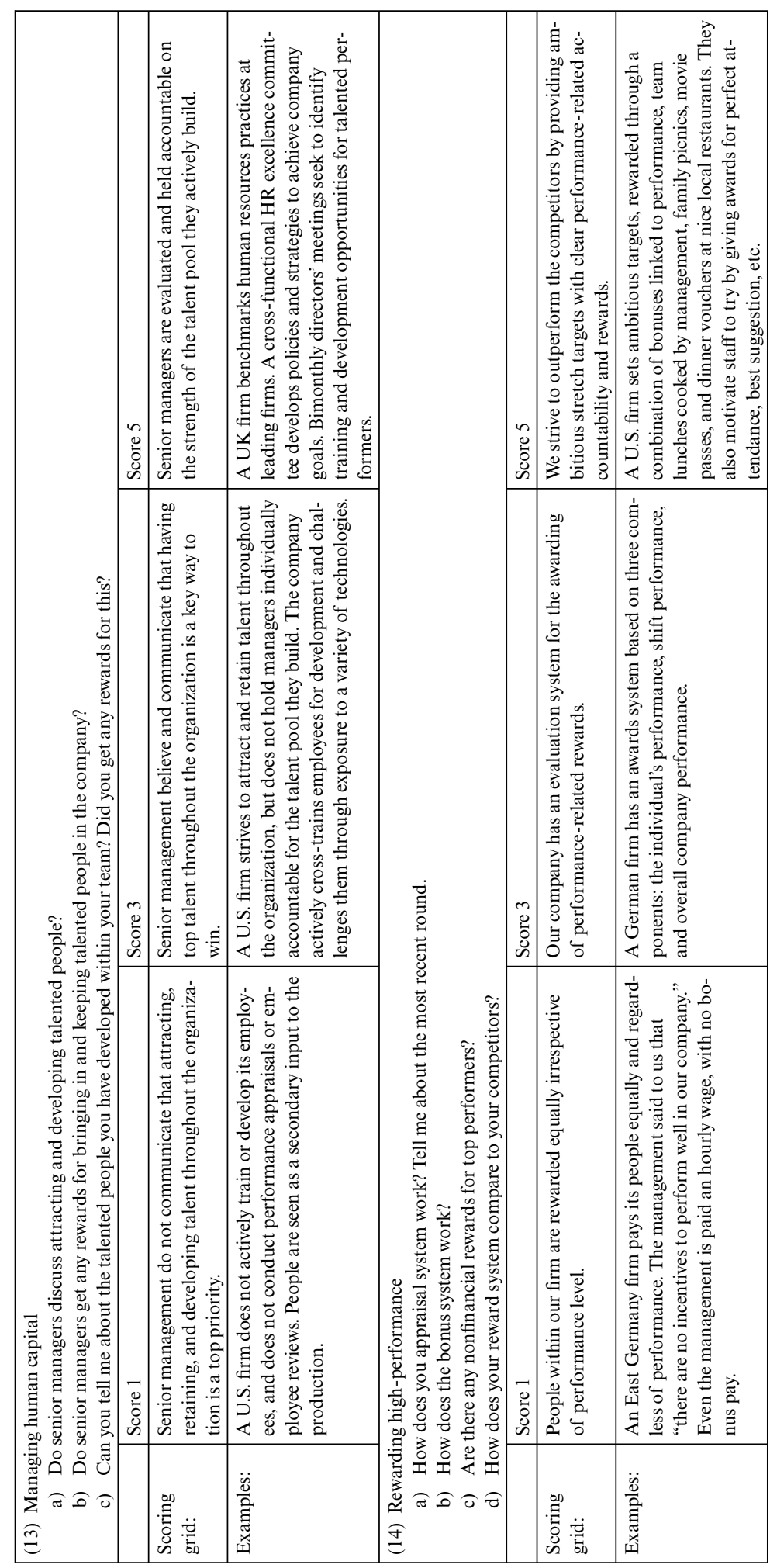




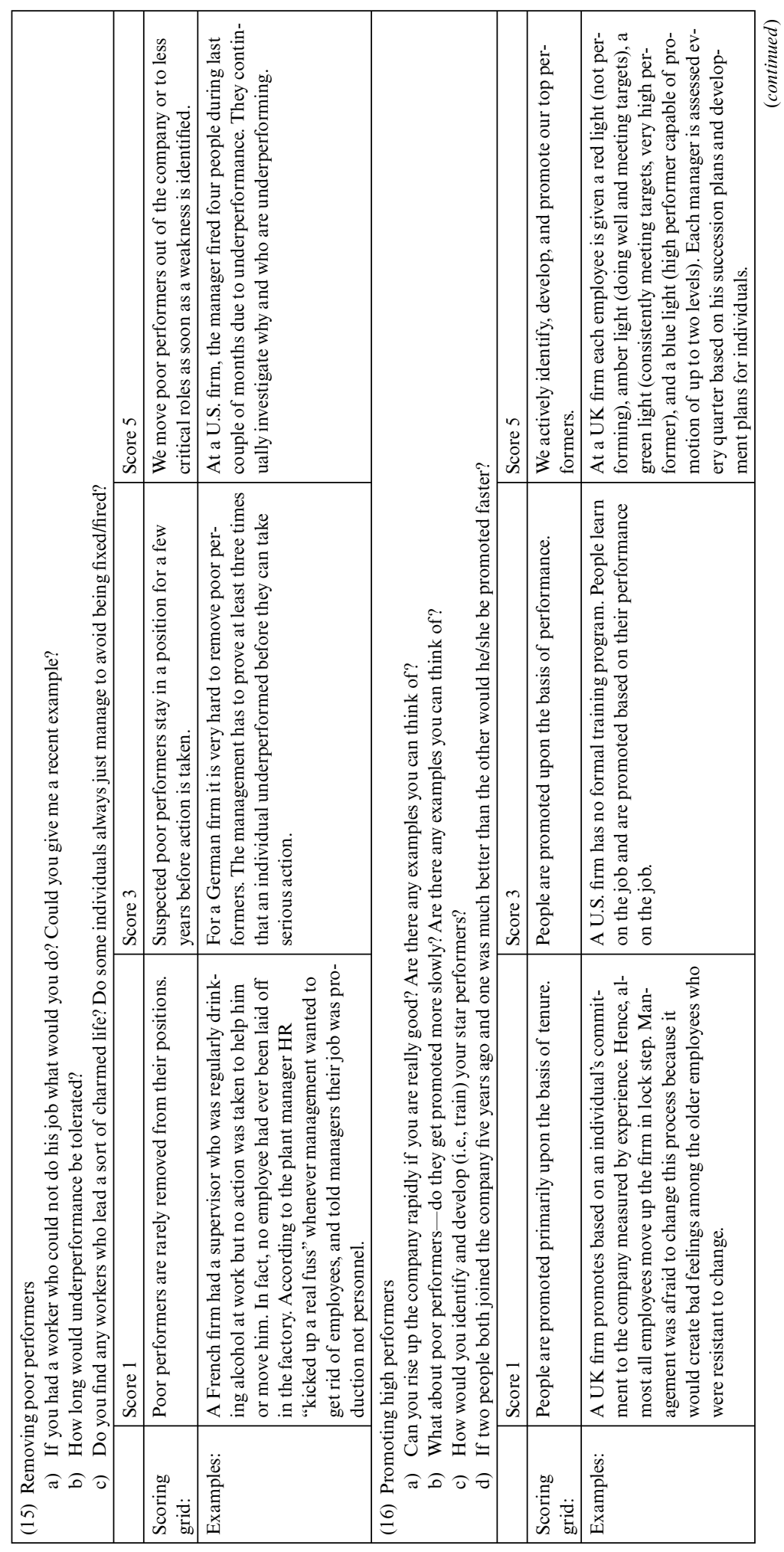




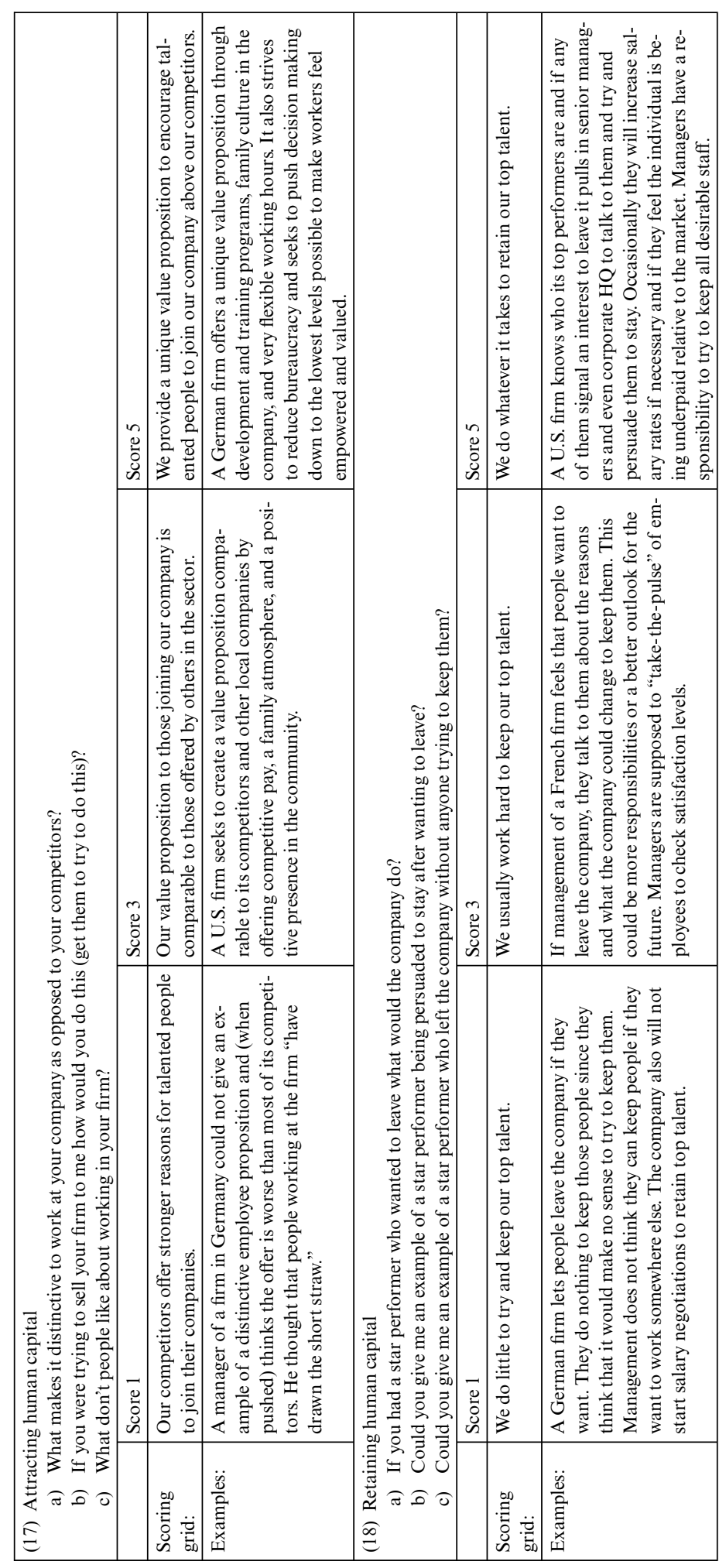




\begin{tabular}{|c|c|c|c|c|c|c|}
\hline \multirow[b]{2}{*}{ Countries } & \multirow[b]{2}{*}{$\begin{array}{l}\text { Question } \\
\text { number }\end{array}$} & \multirow[b]{2}{*}{$\begin{array}{l}\text { Question } \\
\text { type }\end{array}$} & \multicolumn{3}{|c|}{$\begin{array}{l}\text { Average value by country (United } \\
\qquad \text { States }=100)\end{array}$} & \multirow{2}{*}{$\begin{array}{c}\text { Regression } \\
\text { coefficients } \\
\text { (4) } \\
\text { All }\end{array}$} \\
\hline & & & $\begin{array}{l}\text { United } \\
\text { Kingdom }\end{array}$ & $\begin{array}{c}(2) \\
\text { Germany }\end{array}$ & $\begin{array}{c}(3) \\
\text { France }\end{array}$ & \\
\hline $\begin{array}{l}\text { Modern manufacturing, } \\
\text { introduction }\end{array}$ & 1 & Operations & $\begin{array}{l}90.0 \\
(3.50)\end{array}$ & $\begin{array}{l}86.4 \\
(3.47)\end{array}$ & $\begin{array}{l}101.3 \\
(3.63)\end{array}$ & $\begin{array}{l}0.017^{* *} \\
(0.008)\end{array}$ \\
\hline Modern manufacturing, rationale & 2 & Operations & $\begin{array}{l}92.9 \\
(3.35)\end{array}$ & $\begin{array}{l}101.5 \\
(3.32)\end{array}$ & $\begin{array}{l}101 \\
(3.47)\end{array}$ & $\begin{array}{c}0.012 \\
(0.009)\end{array}$ \\
\hline Process documentation & 3 & Operations & $\begin{array}{l}89.0 \\
(3.51)\end{array}$ & $\begin{array}{r}106.9 \\
(3.49)\end{array}$ & $\begin{array}{l}99 \\
(3.64)\end{array}$ & $\begin{array}{l}0.030^{* * *} \\
(0.009)\end{array}$ \\
\hline Performance tracking & 4 & Monitoring & $\begin{array}{l}98.3 \\
(3.19)\end{array}$ & $\begin{array}{l}109.5 \\
(3.17)\end{array}$ & $\begin{array}{l}111 \\
(3.32)\end{array}$ & $\begin{array}{l}0.018^{* *} \\
(0.009)\end{array}$ \\
\hline Performance review & 5 & Monitoring & $\begin{array}{l}94.7 \\
(2.99)\end{array}$ & $\begin{array}{l}110.2 \\
(2.97)\end{array}$ & $\begin{array}{l}104 \\
(3.10)\end{array}$ & $\begin{array}{c}0.016^{*} \\
(0.009)\end{array}$ \\
\hline Performance dialogue & 6 & Monitoring & $\begin{array}{l}93.0 \\
(3.19)\end{array}$ & $\begin{array}{l}103.3 \\
(3.11)\end{array}$ & $\begin{array}{l}99 \\
(3.27)\end{array}$ & $\begin{array}{l}0.019^{* *} \\
(0.009)\end{array}$ \\
\hline Consequence management & 7 & Monitoring & $\begin{array}{l}96.5 \\
(3.02)\end{array}$ & $\begin{array}{r}108.7 \\
(3.01)\end{array}$ & $\begin{array}{l}94 \\
(3.13)\end{array}$ & $\begin{array}{l}0.019^{* *} \\
(0.009)\end{array}$ \\
\hline Target breadth & 8 & Targets & $\begin{array}{l}91.1 \\
(3.53)\end{array}$ & $\begin{array}{l}93.3 \\
(3.51)\end{array}$ & $\begin{array}{l}94 \\
(3.66)\end{array}$ & $\begin{array}{l}0.027^{* * *} \\
(0.009)\end{array}$ \\
\hline Target interconnection & 9 & Targets & $\begin{array}{l}93.7 \\
(3.56)\end{array}$ & $\begin{array}{l}97.3 \\
(3.54)\end{array}$ & $\begin{array}{l}78 \\
(3.68)\end{array}$ & $\begin{array}{l}0.023^{* * *} \\
(0.009)\end{array}$ \\
\hline Target time horizon & 10 & Targets & $\begin{array}{l}91.9 \\
(3.69)\end{array}$ & $\begin{array}{l}98.6 \\
(3.66)\end{array}$ & $\begin{array}{l}92 \\
(3.83)\end{array}$ & $\begin{array}{l}0.021^{* *} \\
(0.009)\end{array}$ \\
\hline Targets are stretching & 11 & Targets & $\begin{array}{l}87.8 \\
(3.34)\end{array}$ & $\begin{array}{r}104.9 \\
(3.32)\end{array}$ & $\begin{array}{l}101 \\
(3.45)\end{array}$ & $\begin{array}{c}0.015^{*} \\
(0.009)\end{array}$ \\
\hline $\begin{array}{l}\text { Performance clarity and } \\
\text { comparability }\end{array}$ & 12 & Monitoring & $\begin{array}{l}93.7 \\
(3.53)\end{array}$ & $\begin{array}{l}80.7 \\
(3.49)\end{array}$ & $\begin{array}{l}83 \\
(3.65)\end{array}$ & $\begin{array}{c}0.008 \\
(0.009)\end{array}$ \\
\hline Managing human capital & 13 & Targets & $\begin{array}{l}89.4 \\
(3.94)\end{array}$ & $\begin{array}{l}99.0 \\
(3.92)\end{array}$ & $\begin{array}{l}89 \\
(4.08)\end{array}$ & $\begin{array}{l}0.023^{* *} \\
(0.009)\end{array}$ \\
\hline Rewarding high performance & 14 & Incentives & $\begin{array}{l}81.6 \\
(3.42)\end{array}$ & $\begin{array}{l}85.2 \\
(3.42)\end{array}$ & $\begin{array}{l}85 \\
(3.55)\end{array}$ & $\begin{array}{l}0.022^{* * *} \\
(0.010)\end{array}$ \\
\hline Removing poor performers & 15 & Incentives & $\begin{array}{l}89.4 \\
(3.04)\end{array}$ & $\begin{array}{l}92.5 \\
(3.02)\end{array}$ & $\begin{array}{l}83 \\
(3.15)\end{array}$ & $\begin{array}{c}0.011 \\
(0.009)\end{array}$ \\
\hline Promoting high performers & 16 & Incentives & $\begin{array}{l}90.2 \\
(2.86)\end{array}$ & $\begin{array}{r}104.9 \\
(2.85)\end{array}$ & $\begin{array}{l}92 \\
(2.97)\end{array}$ & $\begin{array}{l}0.017^{*} \\
(0.010)\end{array}$ \\
\hline Attracting human capital & 17 & Incentives & $\begin{array}{l}90.4 \\
(2.89)\end{array}$ & $\begin{array}{l}95.1 \\
(2.88)\end{array}$ & $\begin{array}{l}85 \\
(2.99)\end{array}$ & $\begin{array}{l}0.029 * * * \\
(0.009)\end{array}$ \\
\hline Retaining human capital & 18 & Incentives & $\begin{array}{l}93.6 \\
(2.74)\end{array}$ & $\begin{array}{l}97.7 \\
(2.73)\end{array}$ & $\begin{array}{l}97 \\
(2.84)\end{array}$ & $\begin{array}{c}0.007 \\
(0.009)\end{array}$ \\
\hline Unweighted average & & & 91.5 & 98.7 & 93.8 & $\begin{array}{c}0.019 \\
(0.009)\end{array}$ \\
\hline
\end{tabular}

Notes: In columns (1) to (3) standard deviation of each question's average response are reported below in brackets. Calculated from full sample of 732 firms. Management $z$-scores used in these calculations. In column (4) results from eighteen OLS estimations following exactly the same specification as column (1) in table 1.2 except estimated with each individual question $z$-score one-by-one rather than the average management $z$-score. So every cell in column (4) is from a different regression with 5,350 observations from 709 firms where: standard errors in parentheses allow for arbitrary heteroskedacity and correlation (clustered by firm), and regression includes "full controls" comprising of "firm" controls and "noise controls" as detailed in table 1.2.

***Significant at the 1 percent level.

**Significant at the 5 percent level.

*Significant at the 10 percent level. 
Table 1A.2

Human Resources interview guide (Run in parallel as the management survey but targeted at the HR department)

\begin{tabular}{ll}
\hline \multicolumn{2}{c}{ Workforce characteristics } \\
\hline Data field & Breakdown \\
\hline $\begin{array}{l}\text { Total number of employees (cross check } \\
\text { against accounts) }\end{array}$ & (All employees) \\
$\begin{array}{l}\% \text { with university degree } \\
\% \text { with MBA }\end{array}$ & (All employees) \\
$\begin{array}{l}\text { Average age of employees } \\
\% \text { of employees }\end{array}$ & (All employees) \\
$\begin{array}{l}\text { Average training days per year } \\
\text { Average hours worked per week (including } \\
\text { overtime, excluding breaks) }\end{array}$ & (All employees) \\
$\begin{array}{l}\text { Average holidays per year } \\
\text { Average days sick-leave }\end{array}$ & (Managerial/Nonmanagerial) \\
$\%$ part-time & (Managerial/Nonmanagerial) \\
$\%$ female & (All employees) \\
$\%$ employees abroad & (All employees) \\
$\%$ union membership & (Managerial/Nonmanagerial) \\
Are unions recognized for wages bargaining & (Managerial/Nonmanagerial) \\
[yes / no] & (All employees) \\
\hline
\end{tabular}

Work-life balance outcome measure:

\begin{tabular}{ll}
\hline Question & Response choice (all employees) \\
\hline $\begin{array}{l}\text { Relative to other companies in your industry } \\
\text { how much does your company emphasize } \\
\text { work-life balance? }\end{array}$ & $\begin{array}{c}\text { [Much less / Slightly less / The same / Slightly more / } \\
\text { Much more] }\end{array}$ \\
\hline
\end{tabular}

Work-life balance practices:

Question Response choice (managerial/nonmanagerial)

If an employee needed to take a day off at short notice due to childcare problems or their child was sick how do they generally do this?

What entitlements are there to the following Working at home in normal working hours? Switching from full-time to part-time work? Job sharing schemes?

Financial subsidy to help pay for childcare?
[Not allowed / Never been asked / Take as leave without pay / Take time off but make it up later / Take as annual leave / Take as sick leave]

Breakdown

(Managerial/Nonmanagerial)

(Managerial/Nonmanagerial)

(Managerial/Nonmanagerial)

(Managerial/Nonmanagerial)

Organizational Characteristics

Question

Who decides the pace of work?

Who decides how tasks should be allocated?

Do you use self-managing teams?
Response choice (all employees)

[Exclusively workers / Mostly workers / Equally /

Mostly managers / Exclusively managers] [Exclusively workers / Mostly workers / Equally /

Mostly managers / Exclusively managers]

[V. heavily / Heavily / Moderately / Slightly / None] 
for the smaller firms. Luckily, the firms in our sampling frame (over fifty workers) are past the threshold for voluntary disclosure (the only exception is for capital in Germany).

We achieved a response rate of 54 percent from the firms that we contacted: a very high success rate given the voluntary nature of participation. Respondents were not significantly more productive than nonresponders. French firms were slightly less likely to respond than firms in the other three countries and all respondents were significantly larger than nonrespondents. Apart from these two factors, respondents seemed randomly spread around our sampling frame.

\section{Firm Level Data}

Our firm accounting data on sales, employment, capital, profits, shareholder equity, long-term debt, market values (for quoted firms), and wages (where available) came from Amadeus (France, Germany, and the United Kingdom) and Compustat (United States). For other data fields we did the following.

Materials. In France and Germany these are line items in the accounts. In the United Kingdom these were constructed by deducting the total wage bill from the cost of goods sold. In the United States these were constructed following the method in Bresnahan, Brynjolfsson, and Hitt (2002). We start with costs of goods sold (COGS) less depreciation (DP) less labor costs (XLR). For firms who do not report labor expenses expenditures we use average wages and benefits at the four-digit industry level (Bartelsman, Becker, and Gray [2000] until 1996 and then Census Average Production Worker Annual Payroll by four-digit North American Industry Classification System [NAICS] code) and multiply this by the firm's reported employment level. This constructed measure is highly correlated at the industry level with materials. Obviously there may be problems with this measure of materials (and therefore value-added), which is why we check robustness to measures without materials.

\section{Industry Level Data}

This comes from the Organization for Economic Cooperation and Development (OECD) STAN database of industrial production. This is provided at the country International Standard Industrial Classification (ISIC) Rev. 3 level and is mapped into US Standard Industrial Classification (SIC) (1997) three (which is our common industry definition in all four countries). 


\begin{tabular}{|c|c|c|c|c|c|}
\hline & All & France & Germany & $\begin{array}{l}\text { United } \\
\text { Kingdom }\end{array}$ & $\begin{array}{l}\text { United } \\
\text { States }\end{array}$ \\
\hline Number of firms & 732 & 135 & 156 & 151 & 290 \\
\hline Work-life balance & 3.21 & 3.44 & 3.03 & 3.19 & 3.22 \\
\hline Management (mean z score) & -0.001 & -0.084 & 0.032 & -0.150 & 0.097 \\
\hline Employment (mean) & 1,984 & 1,213 & 1,816 & 1,735 & 2,569 \\
\hline Labor share of output (\%) & 26.4 & 23.5 & 28.2 & 27.2 & 28.0 \\
\hline Tobin's Q & 1.71 & 1.16 & 1.86 & 2.01 & 0.88 \\
\hline Nominal sales growth rate $(\%)$ & 6.0 & 5.4 & 3.8 & 6.8 & 7.2 \\
\hline Age of firm (years) & 53.4 & 38.6 & 86.8 & 44.7 & 48.4 \\
\hline Listed firm $(\%)$ & 57.2 & 16.1 & 41.0 & 28.5 & 100 \\
\hline Multinational subsidiary (\%) & 5.1 & 8.9 & 7.1 & 9.3 & 0 \\
\hline Share workforce with degrees $(\%)$ & 21.2 & 15.5 & 14.3 & 14.0 & 31.0 \\
\hline Share workforce with an MBA $(\%)$ & 1.36 & 0.23 & 0.09 & 1.28 & 2.73 \\
\hline Sickness, days per year & 6.80 & 8.16 & 8.51 & 6.21 & 5.01 \\
\hline Hours, hours per week & 40.7 & 35.6 & 38.6 & 40.8 & 44.1 \\
\hline Holidays, days per year & 22.7 & 32.2 & 29.7 & 26.9 & 12.4 \\
\hline Union density (\%) & 19.9 & 9.7 & 41.4 & 25.3 & 9.4 \\
\hline \multicolumn{6}{|l|}{ Number of competitors index, $1=$ none, 2} \\
\hline$=\mathrm{a}$ few, $3=$ many & 2.47 & 2.32 & 2.35 & 2.53 & 2.56 \\
\hline Lerner index, excluding the firm itself & 0.055 & 0.040 & 0.071 & 0.040 & 0.060 \\
\hline Trade openness (imports/output) & 0.31 & 0.33 & 0.32 & 0.42 & 0.24 \\
\hline $\begin{array}{l}\text { Childcare flexibility (see table 1A.2; } 1 \text { is none } \\
\text { and } 3 \text { is maximum) }\end{array}$ & \multicolumn{4}{|c|}{ Childcare flexibility (see table 1A.2; 1 is none } & 2.85 \\
\hline Working from home ( $\%$ that allow this) & 31.6 & 23.4 & 31.7 & 44.1 & 30.1 \\
\hline \multicolumn{6}{|l|}{ Switching from full-time to part-time $(\%$} \\
\hline Job-sharing (\% that allow this) & 10.0 & 21.0 & 7.7 & 15.5 & 3.6 \\
\hline Childcare subsidy ( $\%$ that provide this) & 16.6 & 58.5 & 5.3 & 3.4 & 8.4 \\
\hline
\end{tabular}

Notes: Data descriptive calculated on the full sample of 732 firms for which management information is available. 
Table 1B.2

Controls for measurement error

\begin{tabular}{|c|c|c|c|c|}
\hline $\begin{array}{l}\text { Explanatory } \\
\text { variable }\end{array}$ & Definition & Mean & $\begin{array}{l}\text { Coefficient } \\
\text { (s.e.) }\end{array}$ & $\begin{array}{l}\text { Coefficient } \\
\text { (s.e.) }\end{array}$ \\
\hline Male & Respondent is male & 0.982 & $\begin{array}{l}-0.277 \\
(0.128)\end{array}$ & $\begin{array}{l}-0.298 \\
(0.127)\end{array}$ \\
\hline Seniority & $\begin{array}{l}\text { The position of manager in the } \\
\text { organization ( } 1 \text { to } 5)\end{array}$ & 3.08 & $\begin{array}{c}0.074 \\
(0.026)\end{array}$ & $\begin{array}{c}0.073 \\
(0.026)\end{array}$ \\
\hline $\begin{array}{l}\text { Tenure in this } \\
\text { post }\end{array}$ & Years with current job title & 4.88 & $\begin{array}{l}-0.011 \\
(0.007)\end{array}$ & $\begin{array}{l}-0.009 \\
(0.006)\end{array}$ \\
\hline $\begin{array}{l}\text { Tenure in the } \\
\text { company }\end{array}$ & Years with the company & 11.7 & $\begin{array}{c}0.002 \\
(0.004)\end{array}$ & \\
\hline Countries & $\begin{array}{l}\text { Total number of countries } \\
\text { worked in over last ten years }\end{array}$ & 1.19 & $\begin{array}{c}0.085 \\
(0.048)\end{array}$ & $\begin{array}{c}0.092 \\
(0.043)\end{array}$ \\
\hline Organizations & $\begin{array}{l}\text { Total number of organizations } \\
\text { worked in over last ten years }\end{array}$ & 1.66 & $\begin{array}{l}-0.009 \\
(0.032)\end{array}$ & \\
\hline $\begin{array}{l}\text { Manager is } \\
\text { foreign }\end{array}$ & $\begin{array}{l}\text { Manager was born outside the } \\
\text { country s/he works }\end{array}$ & 0.032 & $\begin{array}{l}-0.048 \\
(0.142)\end{array}$ & \\
\hline $\begin{array}{l}\text { Ever worked in } \\
\text { United States }\end{array}$ & $\begin{array}{l}\text { The manager has worked in the } \\
\text { United States at some point }\end{array}$ & 0.425 & $\begin{array}{c}0.103 \\
(0.152)\end{array}$ & \\
\hline $\begin{array}{l}\text { Location of } \\
\text { manager }\end{array}$ & $\begin{array}{l}\text { Manager based onsite (rather } \\
\text { than in corporate HQ) }\end{array}$ & 0.778 & $\begin{array}{c}0.011 \\
(0.063)\end{array}$ & \\
\hline Tuesday & $\begin{array}{l}\text { Day of the week that interview } \\
\text { was conducted (Monday } \\
\text { base) }\end{array}$ & 0.181 & $\begin{array}{c}0.011 \\
(0.062)\end{array}$ & $\begin{array}{c}0.016 \\
(0.086)\end{array}$ \\
\hline Wednesday & $\begin{array}{l}\text { Day of the week that interview } \\
\text { was conducted (Monday } \\
\text { base) }\end{array}$ & 0.280 & $\begin{array}{c}0.017 \\
(0.084)\end{array}$ & $\begin{array}{c}0.014 \\
(0.080)\end{array}$ \\
\hline Thursday & $\begin{array}{l}\text { Day of the week that interview } \\
\text { was conducted (Monday } \\
\text { base) }\end{array}$ & 0.195 & $\begin{array}{c}0.183 \\
(0.088)\end{array}$ & $\begin{array}{c}0.176 \\
(0.088)\end{array}$ \\
\hline Friday & $\begin{array}{l}\text { Day of the week that interview } \\
\text { was conducted (Monday } \\
\text { base) }\end{array}$ & 0.165 & $\begin{array}{c}0.059 \\
(0.090)\end{array}$ & $\begin{array}{c}0.054 \\
(0.090)\end{array}$ \\
\hline $\begin{array}{l}\text { Local time for } \\
\text { manager }\end{array}$ & $\begin{array}{l}\text { The time of the day ( } 24 \text { hour } \\
\text { clock) interview conducted }\end{array}$ & 12.45 & $\begin{array}{l}-0.023 \\
(0.010)\end{array}$ & $\begin{array}{l}-0.022 \\
(0.010)\end{array}$ \\
\hline $\begin{array}{l}\text { Days from start } \\
\text { of project }\end{array}$ & $\begin{array}{l}\text { Count of days since start of the } \\
\text { project }\end{array}$ & 39 & $\begin{array}{c}0.001 \\
(0.001)\end{array}$ & \\
\hline $\begin{array}{c}\text { Duration of } \\
\text { interview }\end{array}$ & $\begin{array}{l}\text { The length of the interview with } \\
\text { manager (in minutes) }\end{array}$ & 46.0 & $\begin{array}{c}0.008 \\
(0.003)\end{array}$ & $\begin{array}{c}0.007 \\
(0.003)\end{array}$ \\
\hline $\begin{array}{r}\text { Number of } \\
\text { contacts }\end{array}$ & $\begin{array}{l}\text { Number of telephone calls to } \\
\text { arrange the interview }\end{array}$ & 5.73 & $\begin{array}{c}0.007 \\
(0.006)\end{array}$ & \\
\hline Reliability score & $\begin{array}{c}\text { Interviewer's subjective ranking } \\
\text { of interview reliability (1 to 5) }\end{array}$ & 4.15 & $\begin{array}{c}0.326 \\
(0.034)\end{array}$ & $\begin{array}{c}0.327 \\
(0.033)\end{array}$ \\
\hline $\begin{array}{l}17 \text { Interviewers } \\
\text { Dummies }\end{array}$ & & & $\begin{array}{l}\mathrm{F}(15,699)=3.05 \\
p \text {-value }=0.000\end{array}$ & $\begin{array}{l}\mathrm{F}(15,699)=3.46 \\
p \text {-value }=0.000\end{array}$ \\
\hline
\end{tabular}

Notes: Dependent variable is Management $z$-score. Coefficients from ordinary least squares (OLS) regressions with standard errors (s.e.) in parentheses (robust to arbitrary heteroskedasticity); single cross section; 3 country dummies and 108 three-digit industry dummies included in the regression; 732 observations. 


\section{References}

Aghion, P., N. Bloom, R. Blundell, R. Griffith, and P. Howitt. 2005. Competition and innovation: An inverted U relationship. Quarterly Journal of Economics 120 (2): 701-28.

Arthur, M. 2003. Share price reactions to work-family initiatives: An institutional perspective. Academy of Management Journal 46 (4): 497-505.

Bartel, A., C. Ichniowski, and K. Shaw. 2004. Using "insider econometrics" to study productivity. American Economic Review 94 (2): 217-23.

Bartelsman, E., R. Becker, and W. Gray. 2000. The NBER manufacturing productivity database. National Bureau of Economic Research. Available at http://www.nber. org/nberces/nbprod96.htm.

Bertrand, M., and S. Mullainathan. 2001. Do people mean what they say? Implications for subjective survey data. American Economic Review Papers and Proceedings 91 (2): 67-72.

Black, S., and L. Lynch. 2001. How to compete: The impact of workplace practices and information technology on productivity. Review of Economics and Statistics 83 (3): 434-45.

Bloom, N., and J. Van Reenen. 2007. Measuring and explaining management practices across firms and countries. Quarterly Journal of Economics (November): 1351-1408.

Bloom, N., C. Genakos, R. Martin, and R. Sadun. 2008. Modern management: Good for the environment or just hot air? NBER Working Paper no. 14394. Cambridge, MA: National Bureau of Economic Research, October.

Bloom, N., T. Kretschmer, and J. Van Reenen. 2009. Determinants and consequences of family-friendly workplace practices-An International Study. LSE/Stanford mimeo.

Bresnahan, T., E. Brynjolfsson, and L. Hitt. 2002. Information technology, workplace organization, and the demand for skilled labor: Firm-level evidence. Quarterly Journal of Economics 117 (1): 339-76.

Budd, J., and K. Mumford. Forthcoming. Family-friendly work practices in Britain: Availability and effective coverage. Human Resource Management.

Delaney, J., and M. Huselid. 1996. The impact of human resource management practices on perceptions of organizational performance. Academy of Management Journal 39 (4): 949-69.

Gray, H. 2002. Family-friendly working: What a performance! An analysis of the relationship between the availability of family friendly policies and establishment performance. Centre for Economic Performance Discussion Paper no. 529.

Gray, M., and J. Tudball. 2003. Family-friendly work practices: Differences within and between workplaces. Journal of Industrial Relations 45 (3): 269-91.

Guthrie, J. 2001. High-involvement work practices, turnover, and productivity: Evidence from New Zealand. Academy of Management Journal 44 (1): 180-90.

Guthrie, J., and L. Roth. 1999. The state, courts and maternity policies in US organizations: Specifying institutional arrangements. American Sociological Review 64:41-63.

Guthrie, J., C. Spell, and R. Nyamori. 2002. Correlates and consequences of high involvement work practices: The role of competitive strategy. International Journal of Human Resource Management 13 (1): 183-97.

Harel, G., S. Tzafrir, and Y. Baruch. 2003. Achieving organizational effectiveness through promotion of women into managerial positions: HRM practice focus. International Journal of Human Resource Management 14 (2): 247-63.

Huselid, M., S. Jackson, and R. Schuler. 1997. Technical and strategic human 
resource management effectiveness as determinants of firm performance. Academy of Management Journal 40 (1): 171-88.

Ichniowski, C., K. Shaw, and G. Prenushi. 1997. The effects of human resource management practices on productivity: A study of steel finishing lines. American Economic Review 87 (3): 291-313.

Konrad, A., and R. Mangel. 2000. The impact of work-life programs on firm productivity. Strategic Management Journal 21 (12): 1225-37.

Lee, J., and D. Miller. 1999. People matter: Commitment to employees, strategy and performance in Korean firms. Strategic Management Journal 20 (6): 579-93.

Manski, C. 2004. Measuring expectations. Econometrica 72 (5): 1329-76.

Martins, L., K. Eddleston, and J. Veiga. 2002. Moderators of the relationship between work-family conflict and career satisfaction. Academy of Management Journal 45 (2): 399-409.

Miliken, F., L. Martins, and H. Morgan. 1998. Explaining organizational responsiveness to work-family issues: The role of human resource executives as issue interpreters. Academy of Management Journal 41 (5): 580-92.

Nickell, S. 1996. Competition and corporate performance. Journal of Political Economy 104 (4): $724-46$.

O'Mahony, M., and B. van Ark, eds. 2003. EU productivity and competitiveness: An industry perspective. Can Europe resume the catching-up process? Luxembourg: Office for Official Publications of the European Communities.

Osterman, P. 1995. Work/family programs and the employment relationship. Administrative Science Quarterly 40 (4): 681-700.

Perry-Smith, J., and T. Blum. 2000. Work-family human resource bundles and perceived organizational performance. Academy of Management Journal 43 (6): $1107-17$.

Pfeffer, J. 1983. Competitive advantage through people. Cambridge, MA: Harvard University Press.

Schuler, R., and I. MacMillan. 1984. Gaining competitive advantage through human resource practices. Human Resource Management 23 (3): 241-55.

Siegel, D. 1997. The impact of investments in computers on manufacturing productivity growth: A multiple-indicators, multiple causes approach. The Review of Economics and Statistics 79:68-78.

Stewart, M. 1990. Union wage differentials, product market influences and the division of rents. Economic Journal 100 (4): 1122-37.

Syverson, C. 2004a. Market structure and productivity: A concrete example. Journal of Political Economy 112 (6): 1181-1222.

Syverson, C. 2004b. Product substitutability and productivity dispersion. Review of Economics and Statistics 86 (2): 534-50.

Youndt, M., S. Snell, J. Dean, and D. Lepak. 1996. Human resource management, manufacturing strategy, and firm performance. Academy of Management Journal 39 (4): 836-66. 